Article

\title{
The Eneolithic/Bronze Age Transition at Tegole di Bovino (Apulia): Geoarchaeological Evidence of Climate Change and Land-Use Shift
}

\author{
Guido S. Mariani ${ }^{1}\left(\mathbb{D}\right.$, Italo M. Muntoni ${ }^{2}$ and Andrea Zerboni ${ }^{3, *(\mathbb{D}}$ \\ 1 Dipartimento di Scienze Chimiche e Geologiche, Università degli Studi di Cagliari, Cittadella Universitaria, \\ Blocco A, I-09042 Monserrato (CA), Italy; guidos.mariani@unica.it \\ 2 Soprintendenza ABAP per le Province di BAT e FG, via Alberto A. Valentini 8, 71121 Foggia, Italy; \\ italomaria.muntoni@beniculturali.it \\ 3 Dipartimento di Scienze della Terra “A. Desio”, Università degli Studi di Milano, Via L. Mangiagalli 34, \\ I-20133 Milano, Italy \\ * Correspondence: andrea.zerboni@unimi.it; Tel.: +39-02-50315292
}

Received: 14 April 2020; Accepted: 8 May 2020; Published: 16 May 2020

\begin{abstract}
Human communities at the transition between the Eneolithic period and the Bronze Age had to rapidly adapt to cultural and climatic changes, which influenced the whole Mediterranean. The exact dynamics involved in this crucial passage are still a matter of discussion. As newer studies have highlighted the key role of climatic fluctuations during this period, their relationship with the human occupation of the landscape are yet to be fully explored. We investigated the infilling of negative structures at the archaeological site of Tegole di Bovino (Apulia, Southern Italy) looking at evidence of the interaction between climate changes and human strategies. The archaeological sedimentary deposits, investigated though geoarchaeological and micromorphological techniques, show the presence of natural and anthropogenic infillings inside most structures. Both human intervention and/or natural events occurred in the last phases of occupation of the site and its subsequent abandonment. The transition to unfavorable climatic conditions in the same period was most likely involved in the abandonment of the site. The possible further impact of human communities on the landscape in that period, testified by multiple other archives, might have in turn had a role in the eventual change in land use.
\end{abstract}

Keywords: geoarchaeology; thin section micromorphology; archaeological site; land-use; Eneolithic/Bronze Age; Apulia

\section{Introduction}

In the last three decades, the geoarchaeological—and especially micromorphologicalinvestigation of archaeological sediments has helped archaeologists in the interpretation of the formation processes of the archaeological record, as well as elucidating the functional aspects of specific archaeological layers or features [1-6]. On the other hand, archaeological sediments preserve paleoenvironmental proxy data helpful in reconstructing the climatic and environmental changes which happened in the life span of ancient settlements [7-11], and which are eventually correlated to the cultural trajectories of archaeological communities. In the case of prehistoric sites, for instance, environmental modifications reconstructed from anthropogenic sediments can be correlated to modifications in subsistence strategies, land-use changes, or the abandonment of settlements [12-16].

In the case of sheltered archaeological sites (caves and rock shelters) [7,10,17-21] or archaeological sequences buried by thick sedimentary covers [22-25], the preservation of the pristine signal of 
sediments is assured by the isolation of deposits from surface processes. Conversely, in the case of open-air archaeological sites laying at the topographic surface or buried by thin sedimentary/soil bodies, the preservation of environmental proxy data is generally obscured by surface processes-namely weathering, pedogenetic processes and/or erosion-which occurred after the abandonment of archaeological sites $[6,9,12,26-29]$. The latter phenomena hamper our ability in reconstructing archaeological and anthropological events. However, the geoarchaeological approach, coupled with the microscopic investigation of natural and anthropogenic sediments' thin sections, allows discerning between the superimposed effects of subsequent processes on sediments $[4,30]$.

Here, we report on the geoarchaeological investigation carried out at the prehistoric archaeological sites of Tegole di Bovino (Apulia, Southern Italy). The site consists of specific archaeological features (canals, postholes, basins) whose sedimentary infilling formed during the abandonment of the settlement at the time of the regional Eneolithic (or Copper Age) to Early Bronze Age transition. In this case study, thin section micromorphology of the infilling of selected archaeological features allowed us (i) to interpret the main sedimentary processes which occurred at the time of the abandonment of the site, and (ii) to correlate them to regional climatic changes, thus (iii) suggesting a possible, climate-triggered land-use change.

\section{General Settings}

\subsection{Geological, Geomorphological, and Palaeoclimatic Background}

The archaeological site of Tegole (Figure 1) is located in the municipality of Bovino (Foggia, Apulia); it lays on the flat top of a small relief that exceeds $200 \mathrm{~m}$ in height [31]. The landform is interpreted in the geological map [32] as part of the belt of alluvial terraces connecting the Apennines of Apulia to the coastal lowlands. The terrace of Tegole formed in the Pleistocene (probably Middle Pleistocene), and was sectioned to the north and south by the Cervaro and Carapelle streams $[31,33]$.

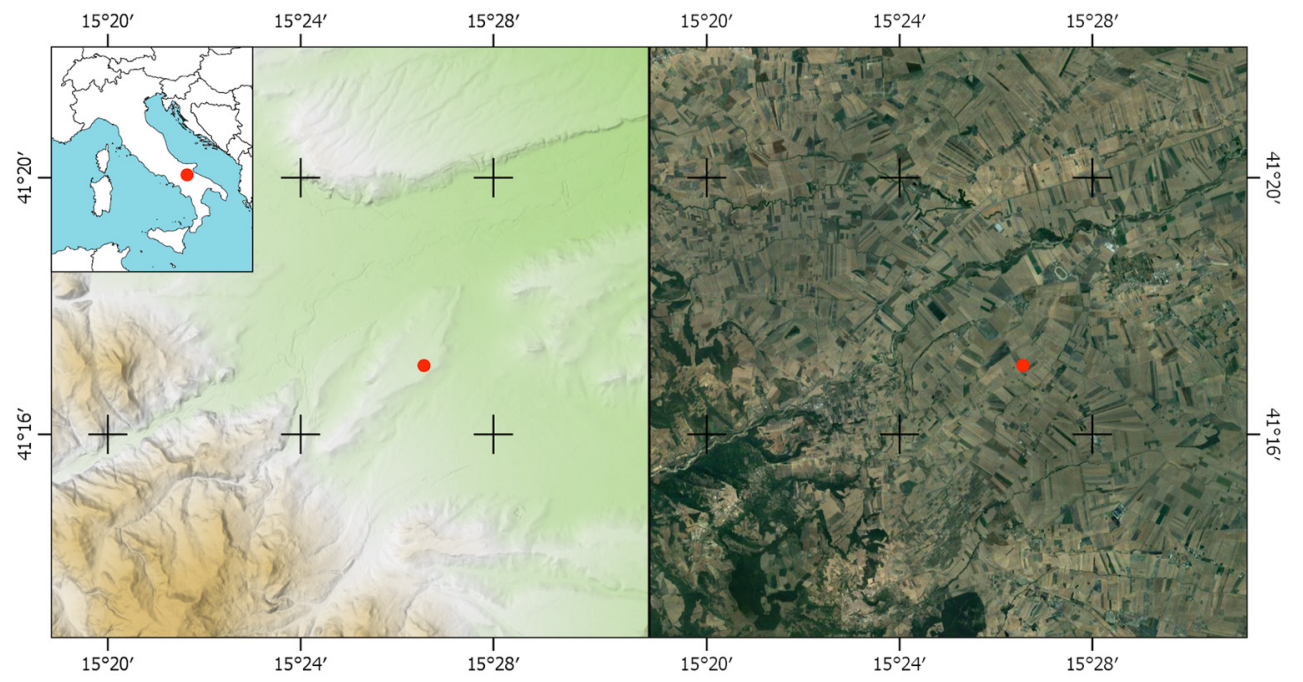

Figure 1. Position of the Tegole di Bovino archaeological site on the GoogleEarth ${ }^{\mathrm{TM}}$ satellite imagine and on a digital elevation model (red dot); in the latter, the relict of Pleistocene terraces at the foot of the Apennines are evident. The inset indicates the position of the study site in Italy.

Geologically, the origin of this region is linked to the Plio-Quaternary evolution of the Southern Apennines foreland-foredeep system [31]. The substrate is consisting of polygenic (mainly carbonates with sandstone pebbles) Middle Pleistocene conglomerates belonging to the Quaternary units of the Apulian Tavoliere. Their appearance is as poorly selected conglomerates with a sandy matrix and sub-rounded clasts originated from Apennine geological formations. The top of the clastic sequence consists of moderately to strongly cemented gravels with sandy matrix. This terrigenous formation 
rests on the Subappennine Clays (Bradanic Trough Unit), composed by weakly stratified clayey silts and grey loamy marls, with intercalations of silty clays and thin layers of sand [32]. The latter formation can be dated to the Calabrian Stage.

From a morphological point of view, the area lies at the passage between the Southern Apennines and the Apulian Tavoliere. The morphological features of the current landscape are directly related to the lithological features and tectonic structures of the area [32]. The connection between the Apennine chain and the Tavoliere plain in the area flanked by the Cervaro and Carapelle streams shows landforms coming from the presence of wide and complex alluvial fan systems spread from the Apennine margin towards the NE. The main rivers have deeply affected the floodplains, opening wide flat-bottomed valleys flowing between the residual fans, broken into multiple separate terraces.

According to several palaeohydrological and pollen-based palaeoclimatic reconstructions, the last 10 millennia can be distinguished in three main phases [34-37] marked by rapid climatic events: (i) an early Holocene phase (before c. $9800 \mathrm{cal}$. years BP) with dry climate conditions in winter and summer, (ii) a mid-Holocene phase (between c. 9800 and c. 4500 cal. years BP) with maximum winter and summer wetness, and a late Holocene period (from c. 4500 cal. years BP onward) with declining winter and summer wetness. Major dry events, whose relevance was discussed also for climatic-cultural changes, occurred at c. 8200 cal. years BP, c. 6000 cal. years BP, c. 4200 cal. years BP, and c. 3000 cal. years BP. More details on the climatic and environmental changes which occurred in Apulia are related to the reconstruction of the expansions and declines of the Mediterranean forest from Lago Alimini Piccolo [38]. This lake registered: a dense evergreen oak forest which dominated the landscape between c. 5200-4350 cal. years BP, the opening of the forest between c. 4350-3900 cal. years BP, new forest expansion (with increase of Olea and Mediterranean evergreen shrubs) between 3900-2100 cal. years BP, a significant opening of the forest and expansion of halophytes in Roman times (2100-1500 cal. years BP), and a strong decrease of the natural woodland (replaced by Olea) after 1500 cal. years BP.

\subsection{Archaeological Framework}

Human influence on landcover, and its degree, is subject to changes according to socio-cultural as well as climate drivers and thus depends on geographical and chronological scales of the case-studies examined. Over the last few years the Apulia region has been extensively investigated by interdisciplinary approaches, mainly focused on archaeobotany, paleobotany and geomorphology, aiming at the a better understanding of the main human-environment interactions during the Neolithic and the Bronze Age periods [39,40]. Using a multidisciplinary approach, palaeoenvironmental and palaeoclimatic data at the regional and Mediterranean scales were compared with the results of analyses performed on natural deposits and deposits in Neolithic and Bronze Age settlements. These studies highlighted the main climatic features of the dry and wet phases, the settlements dynamics, the major transformations of annual crop husbandry, seasonal harvesting strategies and storage technologies that appear to be alternately linked to climate forces, to settlement sizes, distributions and duration and to socio-economical dynamics. In Apulia, Neolithic communities developed a farm-based economy that survived several low-intensity climate oscillations, but the settlement density saw a progressive reduction up to a new expansion at the end of the Neolithic [39]. Several changes in subsistence strategies occurred in subsequent Bronze Age phases and were the responses to both climate/environmental variations and socio-cultural dynamics. Archaeological and archaeobotanical data recorded at least two major transformations of annual crop husbandry and seasonal harvesting strategies, ultimately related to phases of increased aridity and, the most recent, to social triggers [40].

\section{Materials and Methods}

\subsection{Archaeological Excavation}

The archaeological excavation of the site of Tegole di Bovino was performed during 2010 in the framework of rescue archaeology related to the building of a windmill of the Maestrale Green 
Energy company (Figure 2). The area was surveyed, the extant topsoil removed and then extensively excavated on an area of almost $1550 \mathrm{~m}^{2}$ [41], according to the identification of stratigraphic units (SU). Archaeological features and structures were surveyed and recorded with a total station. During the excavation, also the sedimentological and pedological properties for each stratigraphic unit of investigated sections were described; color was described using the Munsell ${ }^{\circledR}$ Color System (1994 revised edition, Munsell ${ }^{\circledR}$ Color, New Windsor, ST, USA). Samples for laboratory analyses and dating were also collected.
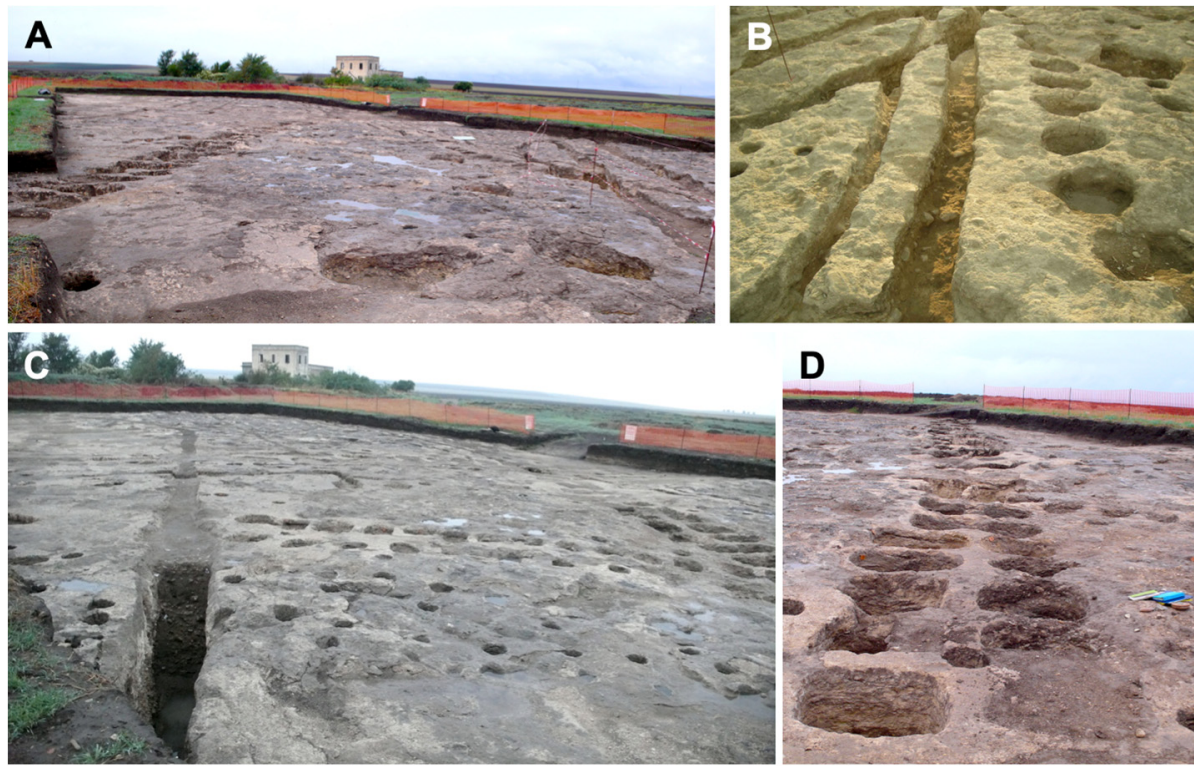

D
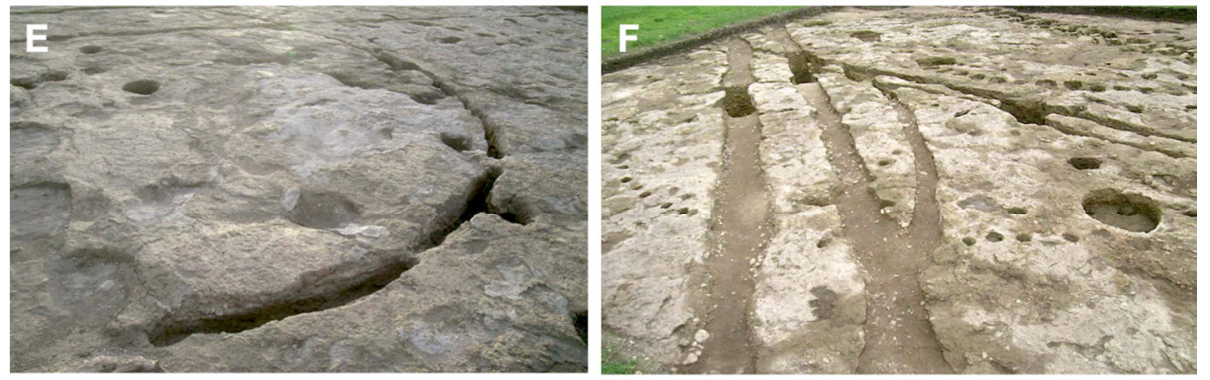

G

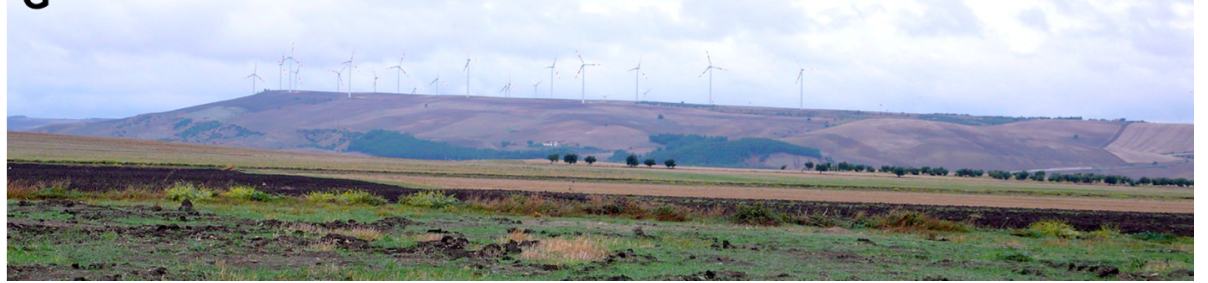

Figure 2. Some views of the Tegole di Bovino archaeological site during the excavation: (A) general view of the excavation; (B) general view of canals and pits; (C,D) views of the alignment of double pits that includes STR41, some postholes are also present; (E) a structures interpreted as the basement of a hut, notice the presence of several postholes; (F) general views of the major canals and alignments of postholes; $(\mathbf{G})$ panoramic view of the Pleistocene terrace.

\subsection{Thin Sections' Analysis}

Oriented and undisturbed sediment blocks from the stratigraphic units of the infilling of selected archaeological structures (small and large canals, double and single post holes) were collected from the main sections. Thin sections $(5 \times 9 \mathrm{~cm})$ were manufactured after consolidation according to the method 
described by Murphy [42]. Micromorphological observation of slides under plane-polarized light (PPL), cross-polarized light (XPL) and oblique incident light (OIL) of thin sections employed an Olympus B41 optical petrographic microscope at various magnifications $(20 \times, 40 \times, 100 \times, 200 \times$ and $400 \times)$ equipped with a digital camera (Olympus E420). For the description of the thin sections, the reader should consider the terminology and concepts established by Stoops [43], whereas interpretation of micromorphological features of natural and anthropogenic sediments follows the indications several guideline books $[1,4,44]$.

\subsection{Archaeological and Radiometric Dating}

The dating of the sequence relies on: (i) the stratigraphic relationship among archaeological features; (ii) the chrono-typological interpretation of archaeological materials found into the same sequence during the archaeological excavation; and (iii) radiocarbon dating of charcoal fragments found during the excavation of the main canals (Canal A and C) and from a well dated in the V phase of the site. Accelerator mass spectrometry (AMS) ${ }^{14} \mathrm{C}$ dating results were calibrated ( $2 \sigma$ calibration) with the online version of the OxCal v4.3 software [45] using to the IntCal13 curve [46].

\section{Results}

In the following section, we report on the data collected at the Tegole di Bovino site. We start by illustrating archaeological data and the chronological framework available for the site, and then we report on data on the infilling of selected negative structures collected in the field and under the microscope.

\subsection{Archaeological Evidence and Dating}

The archaeological excavation of the site revealed a complex system of negative structures including postholes, well, pits, and canals of different shape and length, with different infillings. Figure 3 represents a plan of the excavated area illustrating the distribution of negative features (Figure 2): canals of different width and depth cross the archaeological areas; several large pits are distributed in the eastern part of the area; postholes of different width are aligned across the area. Postholes alignments are of different types: single alignments and postholes in double rows. Distinctive features are the double alignments of large postholes or pits, of which the functional interpretation is still discussed.

According to archaeological interpretation of the findings and stratigraphic criteria, different features can be attributed to at least seven phases of use of the site [47-49] spanning between the IV millennium BC (initial phase of the Eneolithic) up to the II millennium BC (Bronze Age). The I to VI phase can be dated at the beginning of the Eneolithic periods; only several post holes belongs to the VII later phase (Bronze Age). Notwithstanding this, most of the infillings of archaeological structures seems to be accumulated soon after the abandonment of the settlement. Charcoals were found only in the infilling of Canal A and Canal C and in the well 1 (Structure 11) and their dating gave the results reported in Table 1. The infilling of Canal A and Canal C and those of the well 1 (V phase) formed between ca. 4650 and 4400 years BP (5590-4850 years cal. BP). Typological and decorative studies of the ceramic $[47,48]$ confirm some analogies with the local archaeological facies (Piano Conte/Taurasi) of the beginning of the Eneolithic periods in Southern Italy. From the archaeological point of view, no diagnostic materials are recorded from postholes belonging to the VII later phase of the site. 

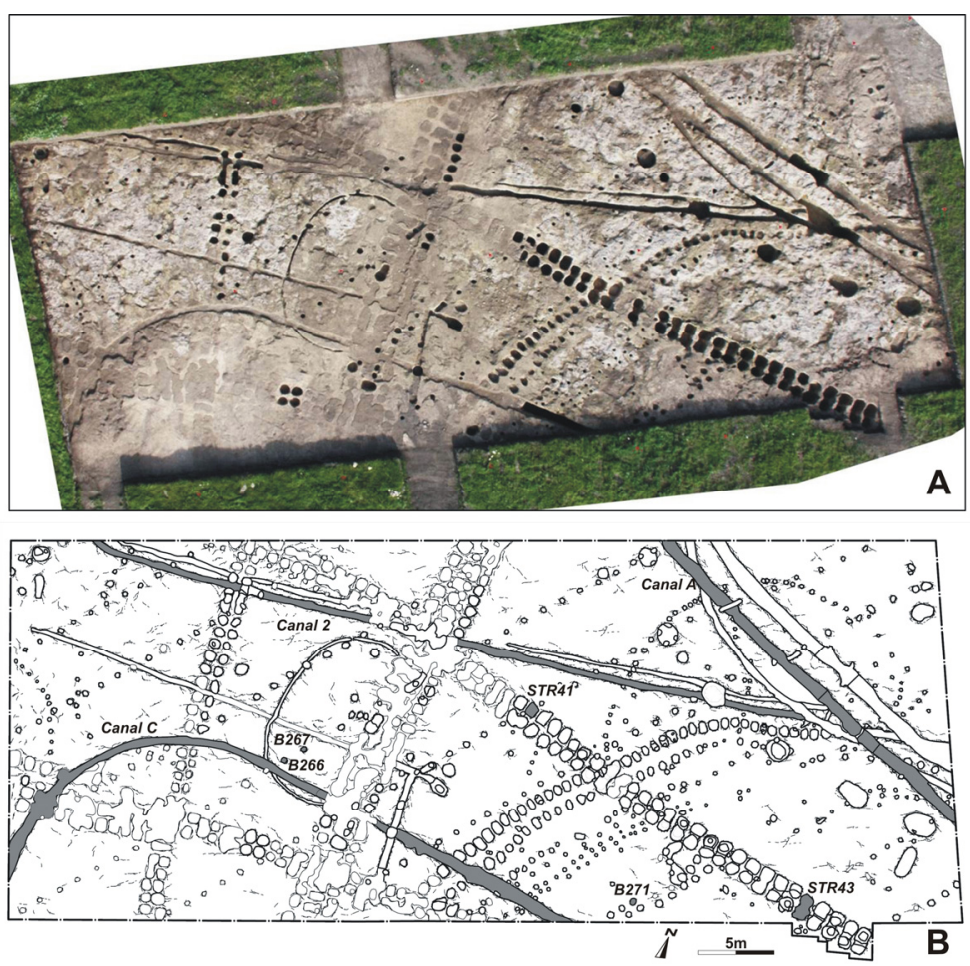

Figure 3. (A) Mosaic of zenithal pictures of the site at the end of the archaeological excavation, and (B) plan of the archaeological excavation indicating the sampled structures.

Table 1. AMS- ${ }^{14} \mathrm{C}$ dating results and $2 \sigma$ calibrations (OxCal v4.3 software [45], IntCal13 curve [46]).

\begin{tabular}{|c|c|c|c|c|c|}
\hline Sample & Laboratory Code & Material & $\delta^{13} C(\% o)$ & ${ }^{14}$ C Years BP & $2 \sigma$ cal. BC \\
\hline Canal A, US 29 & LTL-5407A & charcoal & $-20.8 \pm 0.2$ & $4398 \pm 50$ & $\begin{array}{c}\text { 3330BC }(13.7 \%) 3210 \mathrm{BC} \\
\text { 3180BC }(1.6 \%) 3150 \mathrm{BC} \\
\text { 3130BC }(80.1 \%) 2900 \mathrm{BC}\end{array}$ \\
\hline Canal C, US 687 & LTL-5408A & charcoal & $-18.6 \pm 0.3$ & $4597 \pm 45$ & $\begin{array}{l}3520 \mathrm{BC}(72.1 \%) 3310 \mathrm{BC} \\
3240 \mathrm{BC}(23.3 \%) 3100 \mathrm{BC}\end{array}$ \\
\hline Well, STR11 & LTL-5409A & charcoal & $-28.6 \pm 0.4$ & $4654 \pm 50$ & $\begin{array}{l}3630 \mathrm{BC}(8.2 \%) 3570 \mathrm{BC} \\
3540 \mathrm{BC}(87.2 \%) 3340 \mathrm{BC} \\
3640 \mathrm{BC}(12.2 \%) 3550 \mathrm{BC}\end{array}$ \\
\hline Well, STR11 & LTL-5410A & charcoal & $-39.9 \pm 0.2$ & $4652 \pm 60$ & $\begin{array}{l}3540 \mathrm{BC}(80.9 \%) 3330 \mathrm{BC} \\
3220 \mathrm{BC}(1.4 \%) 3190 \mathrm{BC} \\
3160 \mathrm{BC}(1.0 \%) 3130 \mathrm{BC}\end{array}$ \\
\hline
\end{tabular}

\subsection{Field Evidence of Investigated Structures}

During file operations we described and sampled the infilling of selected structures for microscopic investigation (Figures 2 and 4). Table 2 summarizes the field properties of the archaeological deposits. We sampled the infilling of one of the two long, narrow and shallow canals belonging to the III phase of occupation of the site (Canal 2); these small canals are parallel and run from east to west across the whole archaeological area. Further samples come from the infilling of the deep canals (Canal A and C), they are likely related to water management. We also investigated the infilling of two of the alignments of double pits (SRT41 and STR43, but only SRT41 was sampled) that are characteristic of this site and rarely observed elsewhere; the pit alignments run from SE-NW and to phase VI of the occupation of the village. Finally, we collected samples of the infilling of the postholes B266, B267, and B271 that belong to the VII phase of occupation of the site; features B266 and B267 belong to the same alignment of postholes that cross the whole archaeological area from NE to SW. 

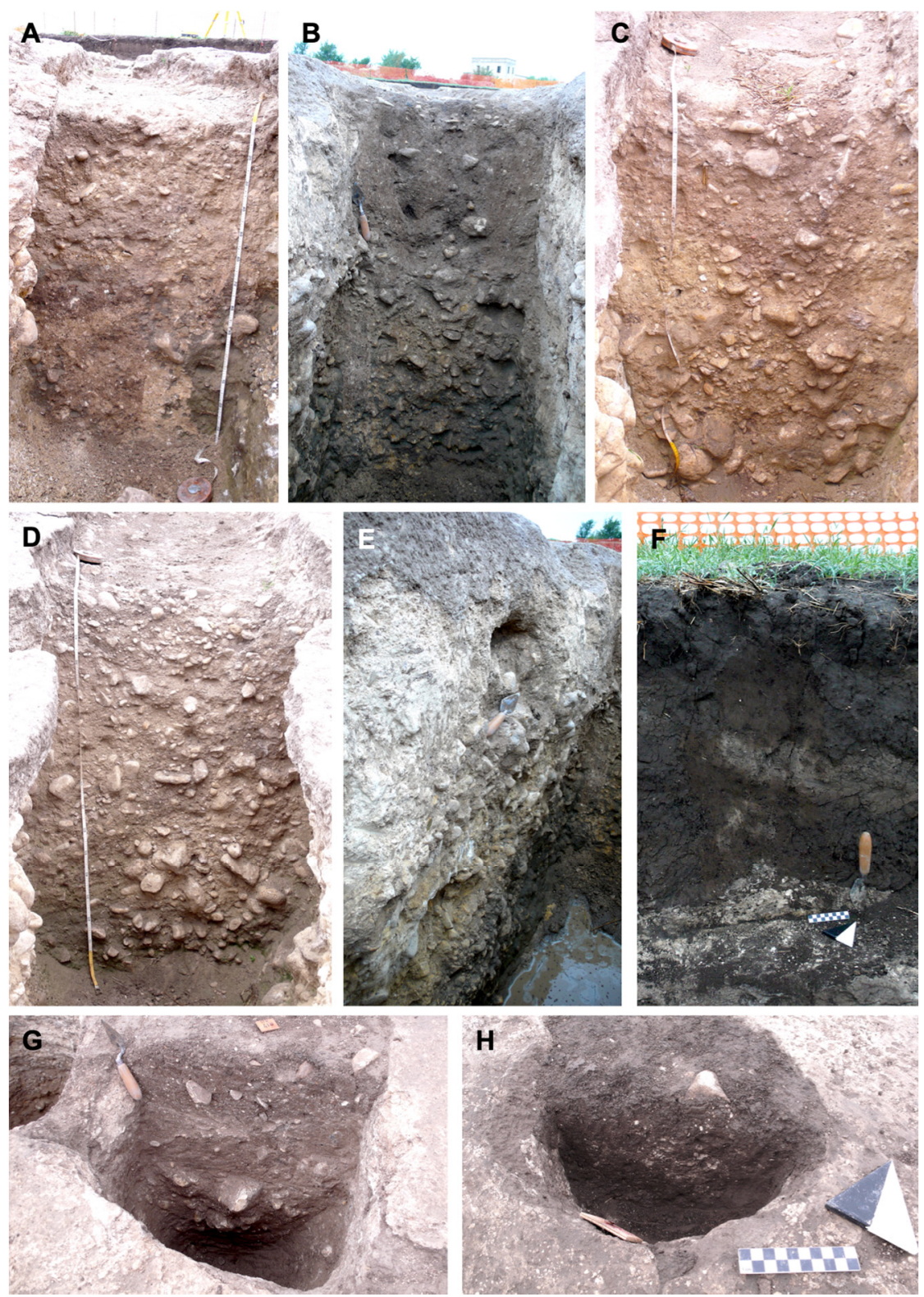

Figure 4. Selected pictures of the stratigraphic sequences investigated at Tegole di Bovino: (A) the infilling of Canal A (note that the lower-left part of the infilling consists of finer material); (B) the infilling of Canal C; (C,D) two examples of the coarse infilling of Canal B; (E) view of the stratigraphy of the bedrock (cemented gravel) of the terrace, where archaeological structures are cut; (F) modern soil of the study area covering the whitish petrocalcic horizon (the crusta); (G) the infilling of pit STR41; (H) the infilling of posthole 266. 
Table 2. Field properties of archaeological infilling; color expressed as Munsell ${ }^{\circledR}$ Color System.

\begin{tabular}{|c|c|c|c|c|c|c|c|c|}
\hline Structure/Unit & Thickness & Color & Texture & Clasts & $\begin{array}{l}\text { Anthropogenic } \\
\text { Components }\end{array}$ & $\begin{array}{l}\text { Sedimentary } \\
\text { Structure }\end{array}$ & Cementation & Pedofeatures \\
\hline Canal A-top & 50 to 110 & $2.5 Y 7 / 6$ & $\begin{array}{l}\text { matrix } \\
\text { supported } \\
\text { gravel }\end{array}$ & heterometric rounded & $\begin{array}{l}\text { rare ceramic } \\
\text { fragments }\end{array}$ & massive & strong & - \\
\hline $\begin{array}{c}\text { Canal } \\
\text { A-bottom }\end{array}$ & 30 to 90 & $\begin{array}{c}2.5 Y 5 / 4 \text { to } 2.5 \mathrm{Y} \\
6 / 4\end{array}$ & silty sand & $\begin{array}{l}\text { rare heterometric } \\
\text { rounded gravel }\end{array}$ & $\begin{array}{l}\text { rare to frequent } \\
\text { charcoals }\end{array}$ & chaotic & moderate & $\begin{array}{l}\text { rare carbonate nodules and } \\
\text { coatings; rare clayey } \\
\text { pedorelicts }\end{array}$ \\
\hline Canal B & 150 & $2.5 Y 7 / 6$ & $\begin{array}{l}\text { matrix to clast } \\
\text { supported } \\
\text { gravel }\end{array}$ & heterometric rounded & - & massive & moderate & absent \\
\hline Canal C-top & 50 & $10 Y R 3 / 6$ & silty loam & $\begin{array}{l}\text { scarce to common } \\
\text { heterometric rounded } \\
\text { gravel }\end{array}$ & $\begin{array}{c}\text { rare } \\
\text { carbonate-encrusted } \\
\text { bone fragments; rare } \\
\text { ceramic fragments }\end{array}$ & massive & weak & $\begin{array}{c}\text { rare carbonate coatings and } \\
\text { impregnations (increasing } \\
\text { downwards) }\end{array}$ \\
\hline $\begin{array}{c}\text { Canal } \\
\text { C-bottom }\end{array}$ & 90 & $10 Y R$ 5/6 & $\begin{array}{l}\text { matrix } \\
\text { supported } \\
\text { gravel }\end{array}$ & heterometric rounded & - & massive & moderate & - \\
\hline Canal 2-top & 15 & $2.5 Y 3 / 2$ & silty clay & $\begin{array}{c}\text { rare heterometric } \\
\text { rounded gravel }\end{array}$ & - & massive & moderate & frequent carbonate coatings \\
\hline $\begin{array}{c}\text { Canal } \\
\text { 2-bottom }\end{array}$ & 35 & $2.5 Y 3 / 2$ & silty clay & $\begin{array}{c}\text { rare heterometric } \\
\text { rounded gravel }\end{array}$ & - & laminated & strong & - \\
\hline STR41-top & 35 & $10 \mathrm{YR} 3 / 3$ & loam & $\begin{array}{l}\text { rare heterometric } \\
\text { rounded gravel }\end{array}$ & $\begin{array}{l}\text { rare ceramic } \\
\text { fragments }\end{array}$ & $\begin{array}{l}\text { massive to } \\
\text { laminated } \\
\text { downwards }\end{array}$ & weak & $\begin{array}{l}\text { few carbonate coatings; } \\
\text { rare carbonate nodules }\end{array}$ \\
\hline STR41-middle & 15 & $10 \mathrm{YR} 4 / 3$ & $\begin{array}{c}\text { clast supported } \\
\text { gravel }\end{array}$ & heterometric rounded & - & massive & weak & - \\
\hline STR41-bottom & 20 & $\begin{array}{l}\text { 10YR } 3 / 2 \text { to } \\
10 Y R 3 / 4\end{array}$ & silty loam & - & - & massive & weak & rare manganese coatings \\
\hline$B 266$ & 30 & $10 \mathrm{YR} 4 / 2$ & silty clay & - & - & massive & - & - \\
\hline$B 267$ & 35 & $10 \mathrm{YR} 4 / 3$ & silty clay & - & rare charcoals & massive & - & $\begin{array}{l}\text { rare carbonate coatings and } \\
\text { impregnations }\end{array}$ \\
\hline$B 271$ & 35 & $10 \mathrm{YR} 4 / 2$ & silty clay & - & - & massive & moderate & $\begin{array}{c}\text { rare carbonate } \\
\text { impregnations (increasing } \\
\text { downwards) }\end{array}$ \\
\hline
\end{tabular}




\subsubsection{Canals}

Canal A (Figure 4) is a deep structure positioned in the central part of the site and attributed to phase V; the deposit has a maximum depth of $140 \mathrm{~cm}$ and is divided into two units. The top unit consists of abundant matrix-supported gravel cemented by calcium carbonate, bearing rare ceramic fragments in a yellow sandy matrix. Its lower boundary is wavy and with a depth varying between 50 and $110 \mathrm{~cm}$. The bottom unit is made up of juxtaposed portions of materials of different color, silty-sandy, with rare coarse materials, small nodules and calcium carbonate coatings as well as clayey aggregates mixed with the rest of the soil mas. This unit can be divided into further sub-units according to charcoal content: Two sub-units are rich in charcoal (CanalA-1 and CanalA-2), and one devoid of them (CanalA-3). Canal B is referred to phase $\mathrm{V}$ and filled with rounded heterometric gravels matrix to clast supported. The matrix consists of yellow sand moderately cemented by carbonates. Canal $\mathrm{C}$ is positioned at the western margin of the excavation and attributed to phase $\mathrm{V}$ (Figure 4). It is about $1 \mathrm{~m}$ wide, $1.5 \mathrm{~m}$ deep and dug into the gravel substrate. Its filling consists of two macro-units. The top unit is about $50 \mathrm{~cm}$ thick and consists of a massive yellowish brown silty-loam deposit. Coatings and concentrations of calcium carbonate are present and increase downwards. There are also rare bone fragments faintly carbonate-encrusted, as well as rare ceramic fragments. The lower unit is about $90 \mathrm{~cm}$ thick and consists of massive heterometric rounded matrix-supported gravel, shifting to clastic support downwards. The matrix is yellowish, sandy-silty and moderately carbonate cemented. Clasts are often covered by carbonate coatings. Canal 2 is a shallow cut at the margin of the excavation area (Figure 4). The top of the filling ( $15 \mathrm{~cm}$ in depth) is silty-clayey, dark brown, massive and fragile with rare coarse material and widespread carbonate coatings. At the passage to the unit below, an increase in calcium carbonate and cementation is present. The bottom unit (down to $50 \mathrm{~cm}$ ) is a yellow silty-clayey deposit with rare coarse material and moderately expressed laminated sedimentary structures strongly carbonate cemented.

\subsubsection{Pits and Postholes}

STR41 corresponds to one of the aligned coupled shallow pits (about $70 \mathrm{~cm}$ deep) located in the central portion of the excavation and belonging to phase VI (Figure 4). Three different fillings are visible. The top deposit, about $35 \mathrm{~cm}$ thick, is brown, loamy and laminated downwards. Laminae are weak and well separated by cracks infilled by calcium carbonate. The coarse material is fine and rare. Rare carbonate nodules and ceramic fragments are observed. For this unit, two different thin sections at different depths were produced and described. The unit below is a layer of heterometric moderately rounded, clast supported gravel with scarce brown sandy-silty matrix showing cementation. The bottom unit is a silty-loamy massive to blocky deposit, variably dark brown in color and showing rare manganese coatings. No coarse materials are present.

B266, B267 and B271 are conical unaligned postholes with a diameter of ca. $30-35 \mathrm{~cm}$ related to the last site phase of occupation of the site (phase VII). The infilling of postholes is uniform for all three structures (Figure 4): silty-clayey, gray-brown, with weakly developed and fragile blocky aggregates. In B267, rare coatings and accumulation surfaces of calcium carbonate as well as fine charcoal fragments are present. B271 shows calcium carbonate concentrations increasing with depth.

\subsubsection{Current Soil and Bedrock of the Archaeological Site}

The area of Tegole di Bovino, including the archaeological area, is covered by a recent soil (Figure 4), organized in several horizons and developed at the top of the so called crusta (from the local slang crust). The soil consists of a sequence of: a dark brown (10YR 3/2) top ploughed horizon rich in organic matter (Ap horizon), granular weak to moderately resistant aggregates, scarce coarse components, abundant roots, porosity from common to abundant, scarce archaeological materials dating to multiple phases, diffuse lower boundary; a moderately thick $\mathrm{B}$ horizon, locally strongly mixed with the one above due to ploughing and an abrupt lower boundary; a strongly $\mathrm{CaCO}_{3}$-cemented $\mathrm{Ck}$ horizon consisting at it top of 
superimposed layers of yellow pale (5Y 8/2) microcrystalline calcite followed by progressively massive and $\mathrm{CaCO}_{3}$-cemented gravel. The bedrock consists of rounded heterometric carbonate/sandstone gravel of the alluvial fan, strongly to moderately cemented, sandy matrix-supported, interspersed with slightly cemented sand lenses (Figure 4). All archaeological features are excavated in the heavily cemented conglomerates forming the substrate. The latter (including the $\mathrm{Ck}$ and $\mathrm{R}$ horizons) consists of a laminated upper part followed by cemented gravel strongly cemented by microcrystalline calcium carbonate, and can be defined as petrocalcic horizon [50-53]. The structure of the petrocalcic horizon here described is comparable with the evolution of the crusta-bearing soils found in the same area at lower elevations. Several authors' reports about the crusta suggest its formation during warm phases of the Upper Pleistocene or Early Holocene [54-56].

\subsection{Micromorphology of Thin Sections}

Table S1 summarizes the micromorphological properties of each thin section obtained from the infilling of the archaeological deposits sampled at Tegole di Bovino.

\subsubsection{Canals}

The bottom level of Canal A has a complex microstructure, granular in aggregation to more subangular blocky, with high porosity partially saturated with calcium carbonate (Figure 5). The level of carbonate impregnation locally produces a massive microstructure. The principal coarse materials are common sub-rounded mineral grains mainly made of carbonate rocks and quartz, accompanied by rare igneous minerals, which are generally slightly rounded. Inside the calcite-impregnated groundmass are present common microfossils and rich carbonate rock fragments (Canal A-1 and Canal A-2) as well as some sandstone fragments (CanalA-3) impregnated with iron oxides. The former are in many cases strongly weathered by dissolution and recrystallization processes. The groundmass is silty-clayey, light in color and strongly impregnated with calcium carbonate, which gives the b-fabric a crystallitic appearance (Figure 5). Organic components are also present as few to common microcharcoals (Figure 6) and shell fragments, and as organic pigment impregnations in areas devoid of charcoals. Large light red-brown centimetric soil aggregates (Figure 5) which are different than the rest of the groundmass can be found, sometimes clustered (Canal A-2). Inside are included concentrations of igneous mineral grains, more frequent than in the general groundmass (Figure 5). The difference between their fabric and the features of the groundmass allows to identify them as pedorelicts (sensu Brewer [57]). Rare yellowish-brown millimetric concentric iron oxide nodules (Canal A-1) are also present (Figure 6). Their nature is not compatible with the current position in the deposits and show irregular margins probably produced by transport. Evidence of irregular margins is also found on some rock fragments bearing surface weathering, as well as some centimetric nodules of microcrystalline calcite (Canal A-2). Pedorelicts are almost absent in CanalA-3: The visible ones are smaller and more yellowish. Pedogenetic features are mainly related to the accumulation of calcium carbonate (Figure 6), forming impregnations which in places become very abundant (Canal A-3). Calcite coatings are visible inside the porosity and on the surface of aggregates and mineral grains. In some cases, incomplete micrite infillings are observed, as well as typical and geodic (Canal A-1) millimetric nodules and rare pendants (CanalA-1) on rock fragments. Successive phases of micrite crystallization are evident as crystals of variable dimensions, as well as acicular crystals scattered inside the porosity (Figure 6). 

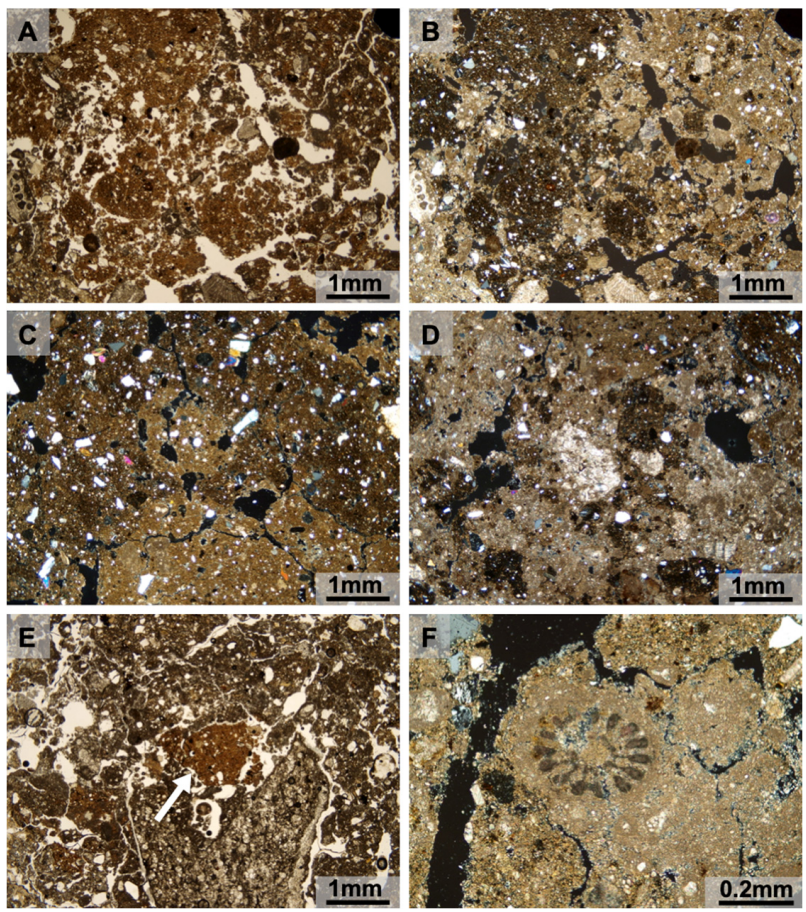

Figure 5. Photomicrographs from the infilling of Canal A and Canal C. (A) Highly porous and complex microstructure (granular to subangular) of the infilling (PPL); (B) the same in XPL, note the impregnation of $\mathrm{CaCO}_{3}$ in the less organic part of the groundmass; (C,D) examples of the different degrees of $\mathrm{CaCO}_{3}$ impregnation of the groundmass, note also the occurrence igneous mineral grains (XPL); (E) the arrow indicates a light red-brown centimetric soil aggregates (pedorelict; PPL); (F) ghost microfossil in a weathered rock fragment (lithorelict; XPL).
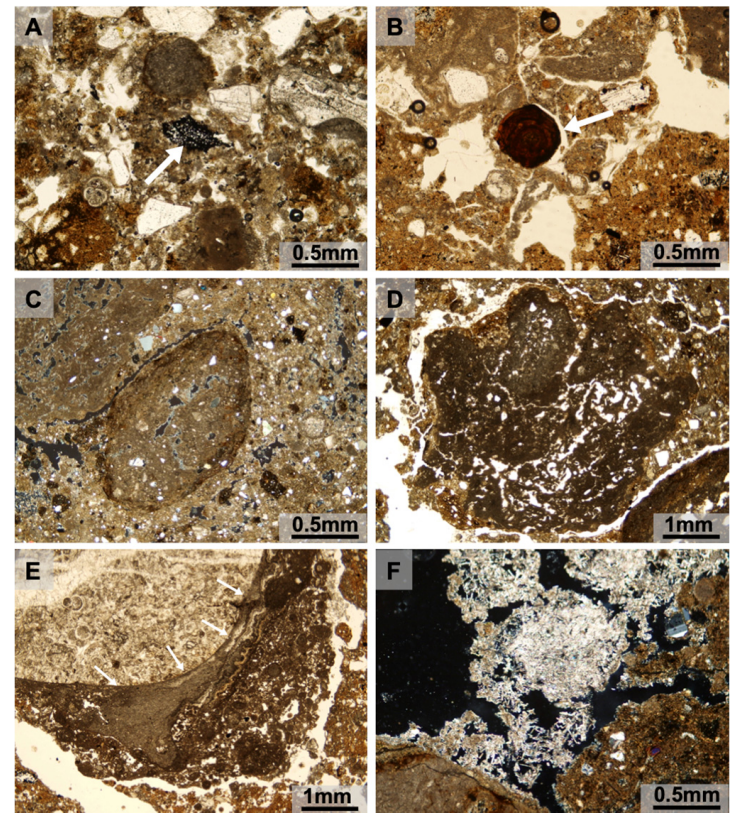

Figure 6. Photomicrographs from the infilling of Canal A and Canal C. (A) The arrow indicates small fragment of charcoal in the groundmass (PPL); (B) the arrow indicates a millimetric concentric iron oxide nodules (PPL); (C,D) calcite nodules in the groundmass (XPL and PPL respectively); (E) arrows indicate a laminated calcite pendent along a rock fragment (PPL); (F) acicular crystals of calcite scattered inside the porosity (XPL). 
The top unit of Canal C shows a subangular blocky microstructure, with weakly separated centimetric aggregates held together by calcite impregnation filling part of the porosity (Figure 5). The lithology of mineral grains is dominated by common carbonate rock fragments and quartz, with a minority of igneous minerals often slightly rounded; few fragments of weakly weathered carbonate rock fragments (lithorelicts) are also visible. The organic fraction is rare and represented by microcharcoals and shell fragments. The groundmass is opaque and yellowish-brown and yellow with two different b-fabrics: a light yellowish crystallitic b-fabric is found associated to carbonate impregnations, while a darker, undifferentiated or granostriated b-fabric is elsewhere, often in combination with concentrations of igneous mineral fragments (Figure 5). Pedofeatures are mainly linked to carbonates: Calcite coatings are visible around voids and on the surface of aggregates and mineral grains (Figure 6). In some cases, incomplete micrite infillings are observed inside voids, as well as millimetric typical and geodic nodules sometimes showing surface weathering. Rare excremental features are visible as accumulations of ellipsoidal faecal pellets in the porosity. The bottom unit is similar to the previous one, with a marked increase in pedofeatures linked to calcite mobilisation. Nodules in particular are more frequent and larger, reaching centimetric dimensions; in addition, acicular calcite concentrations are observed (Figure 6). Conversely, pedofeatures linked to bioturbation are less frequent and smaller in size; among these appear transported clay fragments (papulae sensu Brewer [57]). Laminated coarse textural coatings possibly related to bioturbation are also visible.

The lowest level of Canal 2 consists of parallel sedimentary structures subsequently impregnated with carbonates. Its fabric consists of horizontal, sub-millimetric to centimetric laminae of brown silty clay with an undifferentiated b-fabric, locally crystallitic in higher carbonate impregnated areas. In the central portion laminations are very dense and form stromatolite-like structures (Figure 7). Porosity is completely infilled with carbonates. The rare coarse elements are carbonate rock fragments and, locally, quartz and volcanic mineral grains. Portions of the groundmass contain rounded calcium nodules as well as locally abundant microcharcoals (Figure 7).
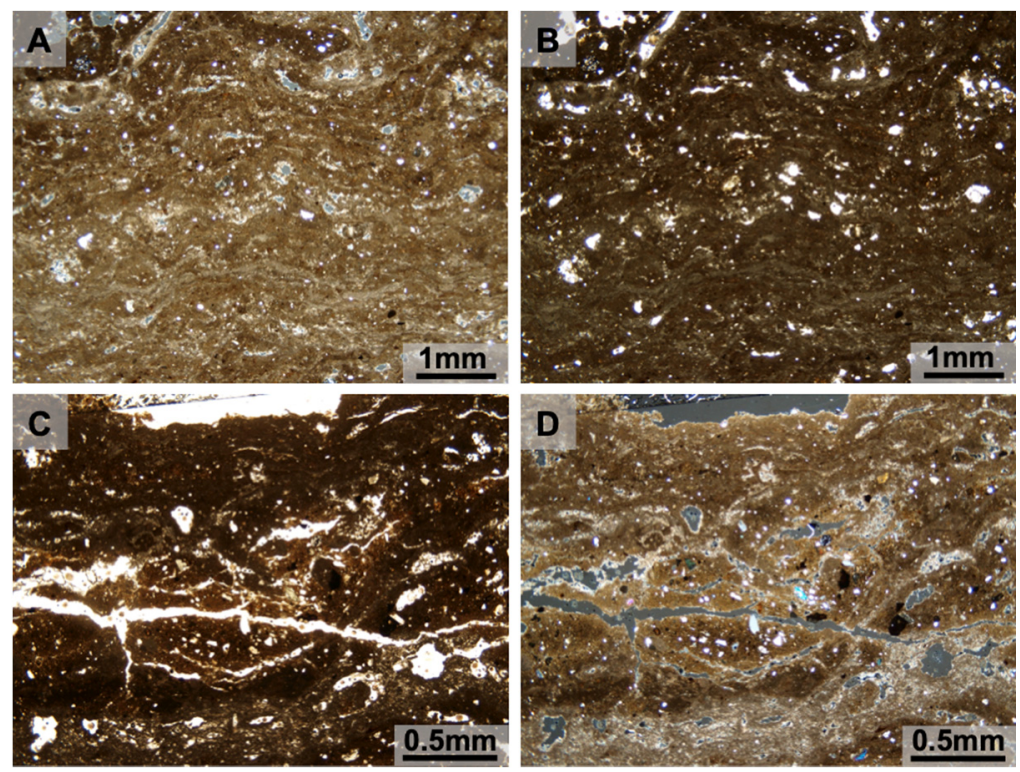

Figure 7. Photomicrographs from the infilling of Canal C. (A) Stromatolite-like structures at the bottom of the canal (XPL); (B) the same in PPL; (C,D) a detail of the laminated structure trapping microcharcoals and igneous mineral grains (PPL and XPL, respectively).

\subsubsection{Postholes and Pits STR41, B266, B267, B271}

The top layer of STR41 has a massive to subangular blocky microstructure, more granular downwards, with common porosity (Figure 8). The groundmass is brown and silty-clayey with common heterometric angular quartz grains and carbonate rock fragments, moderately weathered. 
Igneous mineral grains are observed, rarely with large dimensions. The b-fabric is undifferentiated to crystallitic. The organic constituents are represented by common microcharcoals, partially burnt bone fragments, unburned plant material and small concentrations of sometimes vitrified phytoliths (Figure 8). Pedofeatures are represented mainly by rare carbonate nodules sometimes impregnated with iron, coatings on the surface of coarse grains and moderate impregnations in the groundmass. Calcite infillings are frequent in the lower part, especially inside bioturbation related voids. Pseudomorphic calcite aggregates made of crystal clusters are also locally found as the recrystallization of oxalate pseudomorphs derived from wood ash. Rare thin yellow microlaminated, strongly birefringent clay coatings can be found on some carbonate rock fragments (Figure 8): These are considered to be the remains of an older pedogenetic activity, and therefore interpretable as pedorelicts. The bottom level shows laminations in the upper portion while the rest is massive to subangular blocky. Porosity is common and partly due to bioturbation. The groundmass is silty-clayey and yellowish brown. Frequent heterometric angular quartz and carbonate rock fragments and volcanic mineral grains are observed. The b-fabric is crystallitic, locally striated. The organic constituents are represented by rare microcharcoals and shell fragments. Sub-rounded very fine pedorelicts, dark brown in color and rich in amorphous organic matter and microcharcoals, can be found: these aggregates show visible compression hypocoatings probably due to transport. There is evidence of bioturbation in the form of textural coatings along the channel walls (passage features), sometimes containing ovoid faecal pellets. Other pedofeatures linked to carbonate accumulation are coatings and infillings; the strong impregnation of the groundmass locally forms druses and other macroscopic crystallizations.
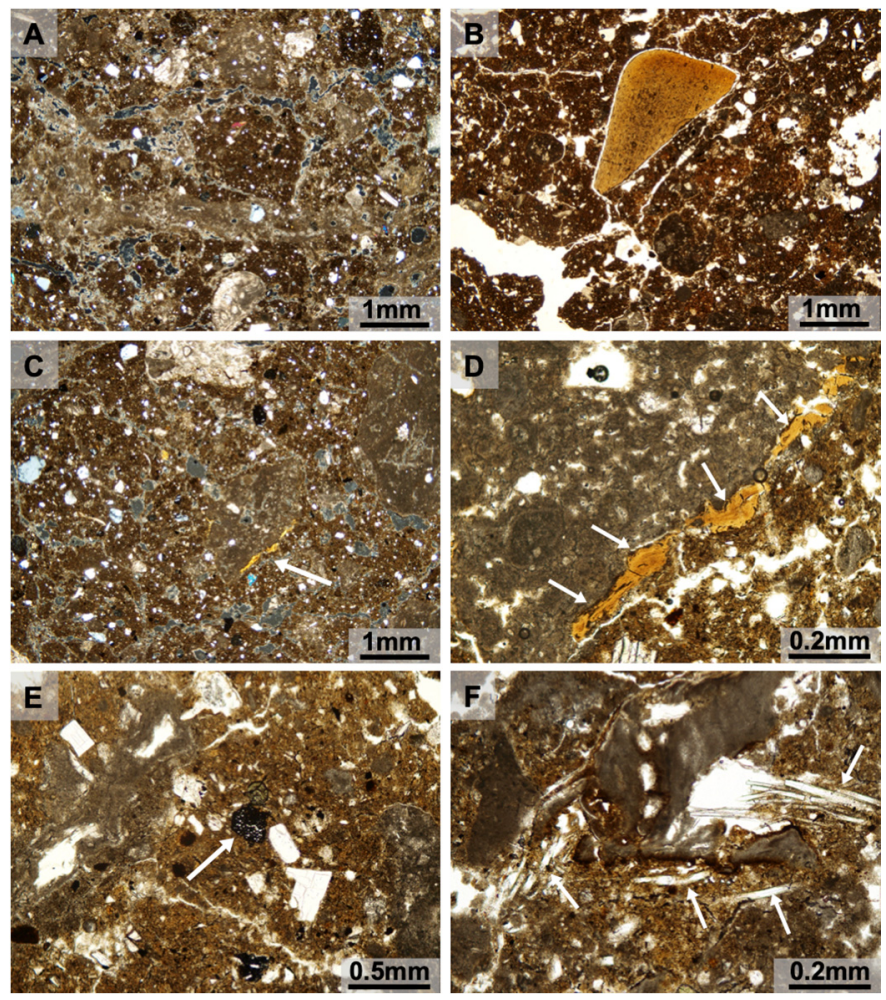

Figure 8. Photomicrographs from the infilling of pit STR41. (A) The groundmass with abundant $\mathrm{CaCO}_{3}$ impregnation and infilling (XPL); (B) a partially burnt bone fragment (PPL); (C) a residual clay coating of a rock fragment (XPL); (D) a detail of the thin yellow microlaminated clay coating (indicated by arrows; PPL); (E) the arrow indicates small fragment of charcoal in the groundmass (PPL); (F) unburned plant material with concentration of phytoliths (indicted by the arrows; PPL).

B266, B267 and B271 are very similar to each other. They show a subangular blocky microstructure (Figure 9), more granular in B271. Voids are frequent, and largely due to bioturbation: In many cases 
porosity contains excremental features. The groundmass is silty-clayey and reddish brown. The mineral fraction is mainly consisting of few angular quartz and rare carbonate rock fragments as well as igneous mineral grains. Organic constituents are very few microcharcoals and rare shell fragments, more frequent in B267 (Figure 9). The groundmass shows an undifferentiated or granostriated b-fabric, locally crystallitic due to micrite impregnation. The pedofeatures observed, in addition to the ellipsoidal faecal pellets inside voids, are mainly related to carbonates. Calcite coatings are found around voids (Figure 9), aggregates and mineral grains; incomplete infillings of micrite and impregnations are also present, as well as typical and geodic millimetric nodules. In B267 the groundmass shows a stronger carbonate impregnation and, conversely, a weaker expression of recrystallization features, with smaller nodules and less calcite infillings. Apart from carbonate pedofeatures, rare amorphous iron oxides nodules and impregnations can also be found in B266. Rare pedorelicts high in organic material are visible in B267, while one pedorelict in B266 shows clear traces of heat action.
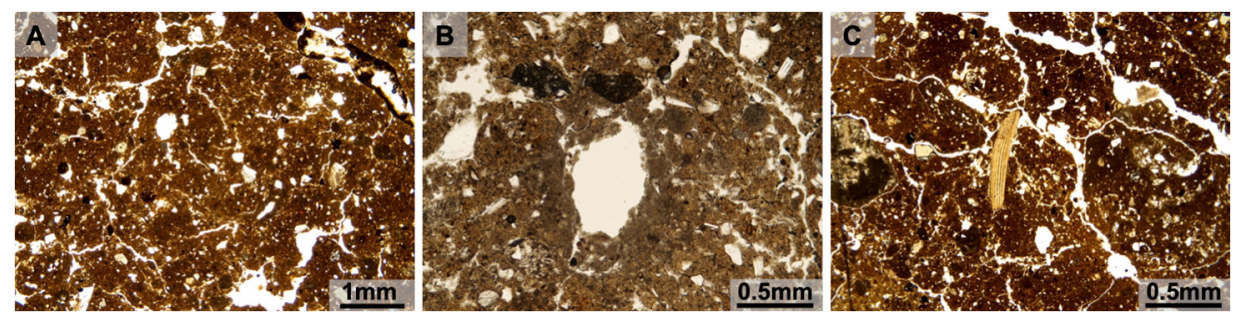

Figure 9. Photomicrographs from the infilling of postholes. (A) Subangular blocky microstructure with microcharcoals interspersed in the groundmass (posthole B266; PPL); (B) calcite coatings around a void in posthole B267 (PPL); (C) fragment of shell in posthole B267 (PPL).

\subsubsection{Petrocalcic Ck Horizon}

The upper part of the petrocalcic horizon consists mainly of dominant rounded blocky aggregates of silty-clayey material and carbonate rock fragments and nodules (Figure 10). All these components are coated with microcrystalline calcite and cemented together by micrite infillings occupying the frequent construction voids as well as the porosity formed by bioturbation. Such cement has formed in successive stages which left different layers of crystalline forms and impurities. Rare silty-loamy pedorelicts rich in organic matter and bearing microcharcoals and igneous mineral granules can also be found inside the porosity. These are not impregnated with micrite, which instead forms a coating around them. At the transition towards the topsoil above is a finely laminated level of clayey material with a stromatolite-like appearance (Figure 10). It contains rare microcharcoals and is strongly impregnated with carbonates, forming micro- or macro-crystalline calcite infillings between the laminae.
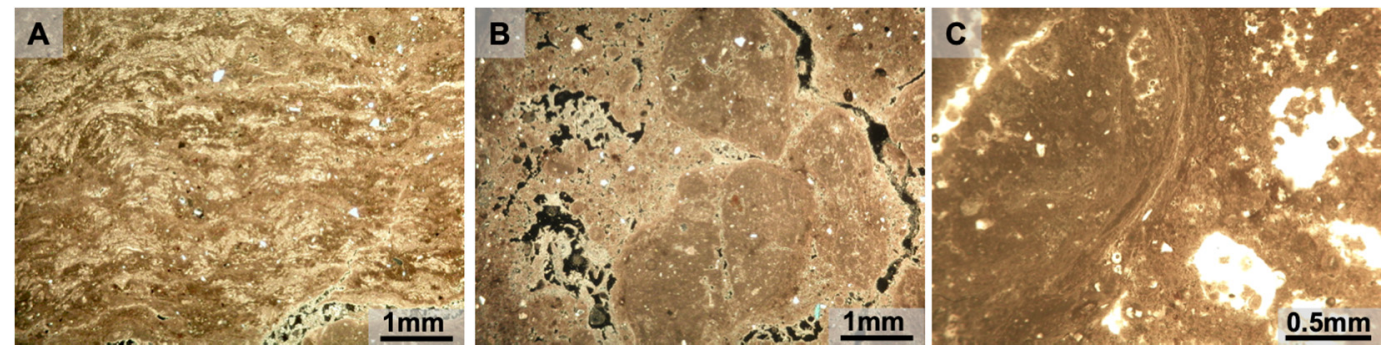

Figure 10. Photomicrographs from the petrocalcic soil horizon (crusta). (A) Stromatolite-like structure of the uppermost part of the horizon (XPL); (B) $\mathrm{CaCO}_{3}$ nodules in the micritic groundmass (XPL); (C) calcitic laminations around a nodule (PPL). 


\section{Discussion}

\subsection{Formation of the Archaeological Record: Natural vs. Anthropogenic Processes}

The deposits inside the deeper canals identified in the excavation area are all characterized by an abundance of coarse material (sandy matrix supported gravels) alternating with lenses or layers of silty, silty-clay or silty-loam deposits. By their features, it is safe to assume that gravel deposits are derived from the substrate (Pleistocene alluvial fans; Figure 4). The presence of such deposits as canal infillings can be related at least to two major reasons. In some cases, they are more plausibly the result of intentional activity than mere natural processes occurred after the abandonment of the structures. For example, Canal B is filled exclusively by gravels from the bedrock of the terrace lacking any sedimentary structure typical of natural deposition (traces of stratification or intercalated lenses). This suggests a human intervention filling the canal with local material after its phase of use. The steps of formation of the infilling of negative archaeological structures at Tegole di Bovino are represented in Figure 11.
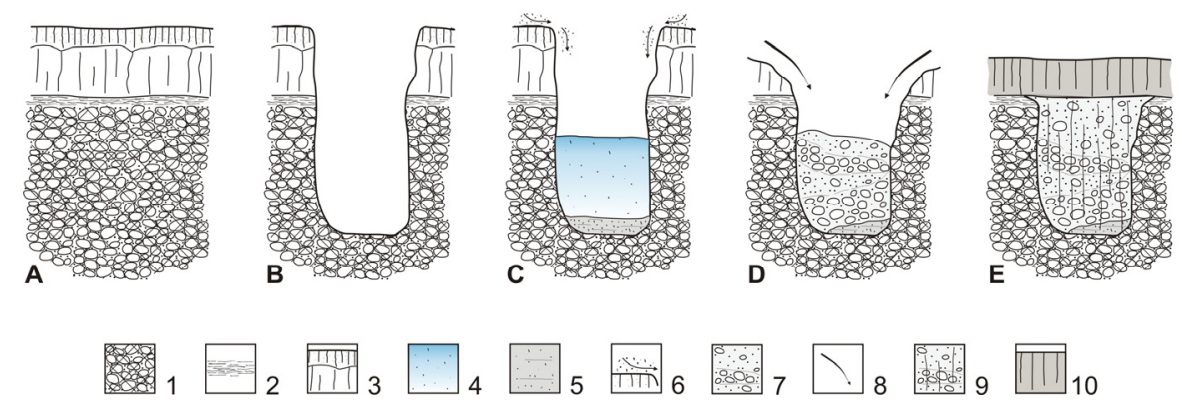

Figure 11. Sketch (not to scale) representing the steps in the evolution of the archaeological site of Tegole di Bovino in relation to environmental and anthropogenic processes. (A) Pristine soil developed on the Pleistocene alluvial fan before the onset of the human settlement. (B) Excavation of archaeological negative features; here we consider the case of canals. (C) Phase of activity of the canal used to collect water; notice the deposition (decantation) of anthropogenic debris from the ground of the archaeological site at the bottom of the canal. During this phase canals were managed and kept empty of debris. (D) Abandonment of the site and infilling of the negative structures with deposits formed by colluvial processes under unstable climatic conditions and increased anthropic pressure (soil loss). (E) After the complete infilling of archaeological structures, $\mathrm{CaCO}_{3}$ remobilization inside the infilling and formation of a fresh topsoil under warm climatic conditions. Key: (1) bedrock of the Pleistocene alluvial fan (conglomerate with $\mathrm{CaCO}_{3}$ cement); (2) laminar part of the crusta; (3) pristine soil; (4) decantation in water; (5) sediment accumulated at the bottom of the canal during the life of the archaeological site; (6) formation of anthropogenic debris from the archaeological site; (7) colluvial deposit in the canal (including matrix-supported and clast-supported components); (8) colluvial processes; (9) infilling of the archaeological feature after calcite remobilization; (10) fresh topsoil.

In other cases, it is still possible to postulate a natural process of infilling through degradation and failure of the side walls $[3,58]$, or at least the occurrence of a natural dismantling process of the margin of the canals and limited human intervention. Thin section micromorphology helps in this task. In fact, the infillings of Canal A and Canal C are very similar in both fabric and composition of the fine and coarse fractions. In the strongly calcite impregnated groundmass of all layers, silty pedorelicts rich in amorphous organic matter and slightly rounded volcanic mineral granules appear. These are quite diagnostic in their nature, and probably represent colluvial material coming from surface horizons of the soils surrounding the archaeological site [59-61], as the relatively higher presence of humified organic matter seems to suggest. The abundance of volcanic minerals could also confirm this interpretation: given that their inheritance from the carbonate parent material is implausible, they were instead probably transported by wind from tephra clouds and accumulated at the surface of the older soil. 
Late Quaternary pyroclastic clouds, originating in the Volture or Campanian regions, have affected the area multiple times $[56,62,63]$ with some events dating to the Holocene $[62,64-66]$, which is compatible with the formation of the topsoil before the archaeological occupation chronology. Even some of the impregnated groundmass could be colluviated from older calcite-rich soil horizons underneath the surface organic ones affected by tephra deposition. Based on this interpretation, the deposit inside Canal $\mathrm{C}$ could have been deposited after its abandonment in a phase of soil degradation (Figure 11). Calcite redeposition is clearly characterised as a post-depositional process $[67,68]$ related to depth, as these impregnations always appear superimposed over the other features. In fact, the main discriminant between the different layers inside Canal $C$ is the passage from prevalent bioturbation features at the top to a progressive appearance of calcite remobilization features towards the bottom. Here, the influence of groundwater fluctuations is stronger, and multiple generations of micritic and acicular calcite show several stages of remobilisation. This process has probably been active until recently $[53,67,69,70]$. Conversely, the deposit in Canal A is divided between a bottom layer rich in charcoals and pedorelicts and a top layer of massive gravels. Both units are possibly anthropogenic in origin and used in turn to fill the canal. The allochthonous origin of the fine bottom deposit is particularly testified by evidence of rearrangement and transport $[61,68]$ even on some carbonate nodules, while the clustered distribution of pedorelicts suggests the use of different materials to fill the canal.

In general, it is possible to observe how the main deposits in the canals are largely formed either by colluvial events or by intentionally dumped material. In both scenarios, the main filling material belongs mainly to surface soil horizons that no longer exist. Canal filling events are plausibly timed during later phases of use or more likely after the abandonment of the Tegole site (Figure 11). In the latter case, the formation of colluvial deposits inside the canals would relate to an increase in climatic instability and reactivation of surface processes consequent to the abandonment itself [60], whereas enhanced colluvial process in a later phase of occupation of the site may be related to a change of local land use. The latter may include the shift from agricultural activities to herding or to intensive cultivation (overgrazing) (Cremaschi et al., 2016). In this setting, the deposit of Canal 2 is instead quite different. The fine laminations of clayey and silty material observed in the field and especially under the microscope suggest a deposition (likely decantation) under water (Figure 11) [71,72]. The presence of anthropogenic constituents (anthropogenic debris) such as microcharcoals inside the laminations point to argue that sedimentation happened while the canal was still in use, therefore during an occupation phase [73,74]. This type of deposit in a small canal implies its purpose as water drainage, only at a later stage influenced by a strong process of carbonate build-up. This canal may have been used to carry and redistribute water collected from the main canals.

The alignments of paired postholes recall in distribution and morphology the foundations for a fence. Their deposits seem to support this hypothesis. In the postholes quite complex layer alternations of fine sediments and gravels with variable thickness are found. At the bottom, the presence of compression surfaces and rounded margins on carbonate nodules and pedorelicts are a sign of the effect of a strong rearrangement $[68,75,76]$. Indications of rearrangement are also visible above. Aside from pedorelicts, the occurrence of clayey coatings around mineral granules is to be connected to the deposition of strongly weathered soils no longer present near the excavation area. The presence within these deposits of ash and charcoal accumulation is significant evidence of fire activity, as well as vitrified phytoliths [9,77]: burned wood in the case of pseudomorphs, herbs for the phytoliths. Combusted material is strictly related to human activity, possibly coming in part from the wooden posts themselves.

In general, micromorphological analysis of postholes deposits showed strong similarities between aligned and isolated holes: Both show strong post-depositional processes linked to carbonate movement in the groundmass. Common microcharcoals suggest the presence of combusted wood while high porosity is an indication of sediment remix $[1,74,78]$. These analogies and the general appearance of the deposits hint at a similar function for all structures: Maybe unsurprisingly, they hosted wooden posts. 
Postholes are attributed though to different times and are not all ascribable to the same archaeological phase. The technique seems similar: all deposits are rather homogeneous, and the features cited above suggest the use of soil material as a stabiliser, in order to fill the spaces left by the wooden posts once in place [79]. This same functional aspect could also be postulated for the aligned coupled holes, considering the evidently reworked soil mass and the abundance of pedorelicts from no longer existing soil horizons.

From all these observations, the origin and formation of the deposits can be unified in a general interpretation. From a macroscopic point of view, most of the filling material seems to be made by gravel coming from the Pleistocene terrace substrate, with evident traces of mixing. The provenance of the gravel highlights the main aspect of the formation of these deposits. It is apparent how the archaeological area generally withstood remediation work in ancient times using the inert material found in the vicinity, interpretable in first approximation as related to the abandonment of the original function of the structures. Slightly different is the case of the basal deposit found in C, which shows juxtaposed fillings rich in charcoal attributable to the dumping of waste material and combustion remains. The micromorphological analysis confirms this interpretation, showing how most of the deposits seem to have originated from colluviation phenomena and/or through intentional filling.

Many of the original features of the deposits are not currently readable. In fact, all sediments have been heavily affected by pedogenetic processes, which acted after their deposition and the abandonment of the site and changed their initial appearance. The main recognisable post-depositional processes are related to the dissolution and recrystallization of calcium carbonate through evapotranspiration. To better understand its effect, a comparison is useful with the calcrete horizon (the crusta) found as the substrate for the archaeological structures. Calcite translocation and recycling have been dominant and prolonged in the study area, as reported in various areas of Apulia [54-56]. These processes, regulated by a typically Mediterranean climate with seasonal variability and particularly dry summer periods, produced an array of pedogenetic features, which mostly obliterated other features of the deposits both at field and microscale. Differently from the crusta itself, the formation of calcite features inside the deposits is delimited by a shorter time span: This caused incomplete cementation and allowed the survival of an array of other pedofeatures. The other main visible post-depositional process is related to bioturbation, mainly as the action of terrestrial invertebrates in the soil mass. The role of other actors in the development of bioturbation features such as vertebrate burrowing and plant root growth is here to exclude, especially in the latter case for the distinctive lack of intact plant remains inside the deposits. From an environmental point of view, it is difficult to give meaningful significance to these features. The action of soil fauna is usually ubiquitous in agricultural areas and most anthropogenic deposits $[1,74]$, where they are not particularly linked to specific environmental or climatic contexts.

The same depositional and post-depositional processes have been described to explain the infilling of the ditch and other structures investigated at the Ripa Tetta Neolithic site, located ca. $20 \mathrm{~km}$ north of Tegole di Bovino, at a lower elevation. At Ripa Tetta, archaeological features are cut in the petrocalcic horizon and the sedimentary infilling of archaeological structures formed during or after the abandonment of the settlement. The infilling of structures was interpreted as the consequences of intentional ripening and colluviation of local soils [58]. Additionally, in this case, the matrix of infilling includes pyroclastic products (interpreted as the consequence of an Early Holocene Vesuvius eruption) and the whole deposit is deeply affected by calcite translocation and recrystallization.

\subsection{Evidence of Climate Change at Tegole di Bovino}

The micromorphological investigation on the sedimentary infilling of the archaeological features at Tegole di Bovino also offers indications of climatic and environmental changes occurred in the region in the Mid-Late Holocene.

The high level of impregnation found is to be related to unfavorable conditions, which were not present at the time of occupation of the site and must be considered active only after this period. In fact, radiocarbon dating obtained from charcoals indicates how structures were filled slightly before the 
Mid-Late Holocene boundary. It is plausible that the passage to warm conditions documented for that phase $[34,36,38,80]$ greatly enhanced evapotranspiration and in turn calcite mobility inside the soils. The low content in calcite of certain portions of the deposits, and especially the pedorelicts, implies a difference in pedogenetic processes during and after the occupation. In fact, the pristine soils in the area apparently lacked strong calcite impregnations, which in turn can be the consequence of a more temperate and humid climate. In the Central Mediterranean region, general wetter climatic conditions are reported from several pollen and palaeohydrological records [35,36,81-85] and recently confirmed for the Southern Adriatic area [80]. In this case water dynamics are driven more by percolation than evapotranspiration and calcite is mostly removed downwards. This also corresponds to the occupation timeframe of the archaeological site: the human community here was active during favorable climatic conditions, which allowed the settlement to prosper.

Similarly, it is possible that variations in the climatic and environmental framework could have been involved also in the final abandonment of the site (Figure 11). In fact, the later phases of occupation of the Tegole di Bovino site and the transition from the Eneolithic to the Early Bronze Age in the area are marked by contrasting climatic conditions. Superimposed to the general trend towards warm conditions, several investigations revealed the occurrence of rapid climatic oscillations $[34,80,86,87]$-including the one at the Northgrippian/Meghalayan transition - that may have enhanced environmental aridity. For the same period, the pollen records from the Lago Alimini Piccolo, Lago Forano, and Fontana Manca lakes in Southern Italy suggest the rapid decline of the forest $[38,88]$. As documented for many other contexts during the Holocene, the climatic instability and rapid oscillations registered during this phase may have reduced the quantity and quality of natural resources (wood, water, soil), thus enhancing the vulnerability of human settlements in the area of Tegole di Bovino. In fact, climatic instability is considered a reliable motor leading to major shifts in subsistence strategies, abandonment of sites, and population relocation [15,89-92]. To adapt to new environmental and climatic conditions, the people of the final phases of the Eneolithic may have adjusted their subsistence strategy and this may have had a consequence on the land use of the area. The rapid decline of the forest registered at this time may have an anthropogenic trigger [93]. Deforestation may have been enhanced by human activities as assessed for the same period and for later periods in other parts of Italy $[14,25,58,84,88]$. Almost for the same reason, colluvial infilling of canals may have been triggered—at least in part-by human activities. Rapid anthropogenic deforestation and/or overgrazing of soils in the context of progressive reduction of water availability [94] may have enhanced the effect of surface processes leading to the dismantling and removal of the pristine Holocene soil cover. Elsewhere, prehistoric and historical records point to the coupled effect of climatic changes-triggered surface processes and human agency as a major cause of soil loss [14,15,29,95-100].

\section{Conclusions}

The findings discovered in the Tegole di Bovino settlement show how climate variations and human subsistence strategies and land use are very strictly intertwined concepts. If these reconstructions will be confirmed by further studies, we can say that the transition from the Eneolithic to the Bronze Age in Apulia was favored by climatic instability and in part by the impact of the human community itself on the landscape through land use choices. The history of this settlement represents another example of the reaction of past communities to perturbations of their life system. In this case, the response to what most likely was a dramatic change in climatic conditions was quite drastic, ending in the abandonment of the site itself.

Active and dynamic environments such as the Mediterranean area, as in this case, often offer only incomplete information since post-depositional processes strongly impact the availability and readability of data. The employment of geoarchaeological techniques allowed nevertheless to recover precious information from the sedimentary deposits on the processes responsible for the filling of the settlement structure, highlighting the events of a crucial phase for the archaeological trajectory of the area [101]. In this, the contribution of microscopic investigations is fundamental: the high level of detail 
obtainable at the microscale is an invaluable tool to understand the nature and features of processes acting on the archaeological record. This allows to retrieve further information on the climatic and human footprint on archaeological sites and on the larger landscape, and to better illustrate how these factors change and interact in time.

Supplementary Materials: The following are available online at http://www.mdpi.com/2571-550X/3/2/14/s1, Table S1: Summary of micromorphological properties of each sample.

Author Contributions: Conceptualization, I.M.M. and A.Z.; analysis, G.S.M. and A.Z.; writing—original draft preparation, G.S.M., I.M.M. and A.Z. All authors have read and agreed to the published version of the manuscript.

Funding: Part of this research was supported by the Italian Ministry of Education, University, and Research (MIUR) through the project "Dipartimenti di Eccellenza 2018-2022" (WP4-Risorse del Patrimonio Culturale) awarded to the Dipartimento di Scienze della Terra "A. Desio" of the Università degli Studi di Milano.

Acknowledgments: The archaeological excavations were performed by Società Cooperativa A.R.A. under the Scientific Direction of Anna Maria Tunzi of the Soprintendenza per i Beni Archeologici della Puglia.

Conflicts of Interest: The authors declare no conflict of interest.

\section{References}

1. Courty, M.A.; Goldberg, P.; Macphail, R. Soils and Micromorphology in Archaeology; Cambridge Manuals in Archaeology; Cambridge University Press: Cambridge, NY, USA, 1989; ISBN 978-0-521-32419-9.

2. Mentzer, S.M. Microarchaeological Approaches to the Identification and Interpretation of Combustion Features in Prehistoric Archaeological Sites. J. Archaeol. Method Theory 2012, 21, 616-668. [CrossRef]

3. Lisá, L.; Komoróczy, B.; Vlach, M.; Válek, D.; Bajer, A.; Kovárník, J.; Rajtár, J.; Hüssen, C.; Šumberová, R. How were the ditches filled? Sedimentological and micromorphological classification of formation processes within graben-like archaeological objects. Quat. Int. 2015, 370, 66-76. [CrossRef]

4. Nicosia, C.; Stoops, G. Archaeological Soil and Sediment Micromorphology; John Wiley \& Sons: Hoboken, NJ, USA, 2017; ISBN 978-1-118-94105-8.

5. Morley, M.W.; Goldberg, P.; Sutikna, T.; Tocheri, M.W.; Prinsloo, L.C.; Jatmiko; Saptomo, E.W.; Wasisto, S.; Roberts, R.G. Initial micromorphological results from Liang Bua, Flores (Indonesia): Site formation processes and hominin activities at the type locality of Homo floresiensis. J. Archaeol. Sci. 2017, 77, 125-142. [CrossRef]

6. Zerboni, A.; Mori, L.; Bosi, G.; Buldrini, F.; Bernasconi, A.; Gatto, M.C.; Mercuri, A.M. Domestic firing activities and fuel consumption in a Saharan oasis: Micromorphological and archaeobotanical evidence from the Garamantian site of Fewet (Central Sahara, SW Libya). J. Arid. Environ. 2017, 144, 123-138. [CrossRef]

7. Goldberg, P. Micromorphology of sediments from Hayonim Cave, Israel. CATENA 1979, 6, 167-181. [CrossRef]

8. Goldberg, P.; MacPhail, R.I. Practical and Theoretical Geoarchaeology; Wiley: Hoboken, NJ, USA, 2005.

9. Zerboni, A. Micromorphology reveals in situ Mesolithic living floors and archaeological features in multiphase sites in central Sudan. Geoarchaeology 2011, 26, 365-391. [CrossRef]

10. Cremaschi, M.; Zerboni, A.; Mercuri, A.M.; Olmi, L.; Biagetti, S.; Di Lernia, S. Takarkori rock shelter (SW Libya): An archive of Holocene climate and environmental changes in the central Sahara. Quat. Sci. Rev. 2014, 101, 36-60. [CrossRef]

11. Goldberg, P.; Aldeias, V. Why does (archaeological) micromorphology have such little traction in (geo)archaeology? Archaeol. Anthropol. Sci. 2016, 10, 269-278. [CrossRef]

12. Karkanas, P. Micromorphological studies of Greek prehistoric sites: New insights in the interpretation of the archaeological record. Geoarchaeology 2002, 17, 237-259. [CrossRef]

13. Tsatskin, A.; Nadel, D. Formation processes at the Ohalo II submerged prehistoric campsite, Israel, inferred from soil micromorphology and magnetic susceptibility studies. Geoarchaeology 2003, 18, 409-432. [CrossRef]

14. Cremaschi, M.; Zerboni, A.; Charpentier, V.; Crassard, R.; Isola, I.; Regattieri, E.; Zanchetta, G. Early-Middle Holocene environmental changes and pre-Neolithic human occupations as recorded in the cavities of Jebel Qara (Dhofar, southern Sultanate of Oman). Quat. Int. 2015, 382, 264-276. [CrossRef]

15. Cremaschi, M.; Mercuri, A.M.; Torri, P.; Florenzano, A.; Pizzi, C.; Marchesini, M.; Zerboni, A. Climate change versus land management in the Po Plain (Northern Italy) during the Bronze Age: New insights from the VP/VG sequence of the Terramara Santa Rosa di Poviglio. Quat. Sci. Rev. 2016, 136, 153-172. [CrossRef] 
16. Maritan, L.; Iacumin, P.; Zerboni, A.; Venturelli, G.; Sasso, G.D.; Linseele, V.; Talamo, S.; Salvatori, S.; Usai, D. Fish and salt: The successful recipe of White Nile Mesolithic hunter-gatherer-fishers. J. Archaeol. Sci. 2018, 92, 48-62. [CrossRef]

17. Goldberg, P. Some micromorphological aspects of prehistoric cave deposits. Cah. D'Archéol. CELAT 2001, 10, 161-175.

18. Shahack-Gross, R.; Berna, F.; Karkanas, P.; Weiner, S. Bat guano and preservation of archaeological remains in cave sites. J. Archaeol. Sci. 2004, 31, 1259-1272. [CrossRef]

19. Angelucci, D.E.; Anesin, D.; Susini, D.; Villaverde, V.; Zapata, J.; Zilhão, J. Formation processes at a high resolution Middle Paleolithic site: Cueva Antón (Murcia, Spain). Quat. Int. 2013, 315, 24-41. [CrossRef]

20. Stahlschmidt, M.; Miller, C.; Kandel, A.; Goldberg, P.; Conard, N. Site formation processes and Late Natufian domestic spaces at Baaz Rockshelter, Syria: A micromorphological perspective. J. Archaeol. Sci. Rep. 2017, 12, 499-514. [CrossRef]

21. Morley, M.W.; Goldberg, P.; Uliyanov, V.A.; Kozlikin, M.B.; Shunkov, M.V.; Derevianko, A.P.; Jacobs, Z.; Roberts, R.G. Hominin and animal activities in the microstratigraphic record from Denisova Cave (Altai Mountains, Russia). Sci. Rep. 2019, 9, 13785-13812. [CrossRef]

22. Dalrymple, J.B. The Application of Soil Micromorphology to Fossil Soils and Other Deposits from Archaeological Sites. J. Soil Sci. 1958, 9, 199-209. [CrossRef]

23. Simpson, I.; Dockrill, S.; Bull, I.; Evershed, R.P. Early Anthropogenic Soil Formation at Tofts Ness, Sanday, Orkney. J. Archaeol. Sci. 1998, 25, 729-746. [CrossRef]

24. Kooistra, M.J.; Kooistra, L.I. Integrated research in archaeology using soil micromorphology and palynology. Catena 2003, 54, 603-617. [CrossRef]

25. Cremaschi, M.; Nicosia, C. Sub-Boreal aggradation along the Apennine margin of the Central Po Plain: Geomorphological and geoarchaeological aspects. Géomorphol. Relief Process. Environ. 2012, 18, 155-174. [CrossRef]

26. Mallol, C.; Marlowe, F.W.; Wood, B.M.; Porter, C.C. Earth, wind, and fire: Ethnoarchaeological signals of Hadza fires. J. Archaeol. Sci. 2007, 34, 2035-2052. [CrossRef]

27. Balbo, A.L.; Madella, M.; Vila, A.; Estévez, J. Micromorphological perspectives on the stratigraphical excavation of shell middens: A first approximation from the ethnohistorical site Tunel VII, Tierra del Fuego (Argentina). J. Archaeol. Sci. 2010, 37, 1252-1259. [CrossRef]

28. Friesem, D.; Zaidner, Y.; Shahack-Gross, R. Formation processes and combustion features at the lower layers of the Middle Palaeolithic open-air site of Nesher Ramla, Israel. Quat. Int. 2014, 331, 128-138. [CrossRef]

29. Zerboni, A.; Bernasconi, A.; Gatto, M.C.; Ottomano, C.; Cremaschi, M.; Mori, L. Building on an oasis in Garamantian times: Geoarchaeological investigation on mud architectural elements from the excavation of Fewet (Central Sahara, SW Libya). J. Arid. Environ. 2018, 157, 149-167. [CrossRef]

30. Cremaschi, M.; Trombino, L.; Zerboni, A. Palaeosoils and Relict Soils. In Interpretation of Micromorphological Features of Soils and Regoliths; Elsevier BV: Amsterdam, The Netherland, 2018; pp. 863-894.

31. ISPRA Carta Geologica D'Italia alla Scala 1: 50.000, Foglio 421 "Ascoli Satriano"; Istituto Superiore per la Protezione e la Ricerca Ambientale: Roma, Italy, 2011.

32. Ciaranfi, N.; Gallicchio, S.; Loiacono, F. Note Illustrative della Carta Geologica D'Italia alla Scala 1: 50.000, Foglio 421 "Ascoli Satriano"; Istituto Superiore per la Protezione e la Ricerca Ambientale: Roma, Italy, 2011.

33. Caldara, M.A.; Pennetta, L. Nuovi dati per la conoscenza geologica e morfologica del Tavoliere di Puglia. Bonifica 1993, 8, 25-42.

34. Giraudi, C.; Magny, M.; Zanchetta, G.; Drysdale, R.N. The Holocene climatic evolution of Mediterranean Italy: A review of the continental geological data. Holocene 2011, 21, 105-115. [CrossRef]

35. Mercuri, A.M.; Sadori, L.; Ollero, P.U. Mediterranean and north-African cultural adaptations to mid-Holocene environmental and climatic changes. Holocene 2011, 21, 189-206. [CrossRef]

36. Sadori, L.; Jahns, S.; Peyron, O. Mid-Holocene vegetation history of the central Mediterranean. Holocene 2011, 21, 117-129. [CrossRef]

37. Magny, M.; Peyron, O.; Sadori, L.; Ortu, E.; Zanchetta, G.; Vannière, B.; Tinner, W. Contrasting patterns of precipitation seasonality during the Holocene in the south- and north-central Mediterranean. J. Quat. Sci. 2011, 27, 290-296. [CrossRef] 
38. Di Rita, F.; Magri, D. Holocene drought, deforestation and evergreen vegetation development in the central Mediterranean: A 5500 year record from Lago Alimini Piccolo, Apulia, southeast Italy. Holocene 2009, 19, 295-306. [CrossRef]

39. Fiorentino, G.; Caldara, M.; De Santis, V.; D’Oronzo, C.; Muntoni, I.M.; Simone, O.; Primavera, M.; Radina, F. Climate changes and human-environment interactions in the Apulia region of southeastern Italy during the Neolithic period. Holocene 2013, 23, 1297-1316. [CrossRef]

40. Primavera, M.; D'Oronzo, C.; Muntoni, I.; Radina, F.; Fiorentino, G. Environment, crops and harvesting strategies during the II millennium BC: Resilience and adaptation in socio-economic systems of Bronze Age communities in Apulia (SE Italy). Quat. Int. 2017, 436, 83-95. [CrossRef]

41. Tunzi, A.M. Tegole. In Venti del Neolitico, Uomini del Rame. Preistoria della Puglia Settentrionale; Tunzi, A.M., Ed.; Claudio Grenzi Editore: Foggia, Italy, 2015.

42. Murphy, C.P. Thin Section Preparation of Soils and Sediments; A B Academic Pub.: Berkhamsted, UK, 1986.

43. Stoops, G. Guidelines for Analysis and Description of Soil and Regolith Thin Sections; Soil Science Society of America, Inc.: Madison, WI, USA, 2003.

44. Stoops, G.; Marcelino, V.; Mees, F. Interpretation of Micromorphological Features of Soils and Regoliths, 2nd ed.; Elsevier: Amsterdam, The Netherland, 2018; ISBN 978-0-444-63542-6.

45. Ramsey, C.B.; Lee, S. Recent and Planned Developments of the Program OxCal. Radiocarbon 2013, 55, 720-730. [CrossRef]

46. Reimer, P.J.; Bard, E.; Bayliss, A.; Beck, J.W.; Blackwell, P.G.; Ramsey, C.B.; E Buck, C.; Cheng, H.; Edwards, R.L.; Friedrich, M.; et al. IntCal13 and Marine13 Radiocarbon Age Calibration Curves 0-50,000 Years cal BP. Radiocarbon 2013, 55, 1869-1887. [CrossRef]

47. Tunzi, A.M.; Lozupone, M.; Bubba, D.; Martino, F.M.; Diomede, G.; Malorgio, M. L'insediamento neo-eneolitico di Tegole (Bovino-Fg). AttiDaunia 2012, 32, 75-99.

48. Tunzi, A.M.; Lo Zupone, M.; Bubba, D.; Gasperi, N. Strutture di abitato e aree produttive dell'età del Rame nella Puglia settentrionale. In Preistoria e Protostoria della Puglia; Radina, F., Ed.; Istituto Italiano di Preistoria e Protostoria, Via della Pergola: Firenze, Italy, 2017; pp. 397-402.

49. Muntoni, I.M.; Zerboni, A. Le strutture insediative di Tegole (Bovino): Analisi geoarcheologiche dei riempimenti. In Preistoria e Protostoria della Puglia; Radina, F., Ed.; Studi di Preistoria e Protostoria; Istituto Italiano di Preistoria e Protostoria: Firenze, Italy, 2017; pp. 829-834, ISBN 978-88-6045-060-9.

50. Wright, V. A Micromorphological Classification of Fossil and Recent Calcic and Petrocalcic Microstructures. In Developments in Soil Science; Elsevier BV: Amsterdam, The Netherland, 1990; Volume 19, pp. 401-407.

51. Achyuthan, H. Petrologic analysis and geochemistry of the Late Neogene-Early Quaternary hardpan calcretes of Western Rajasthan, India. Quat. Int. 2003, 106, 3-10. [CrossRef]

52. Shankar, N.; Achyuthan, H. Genesis of calcic and petrocalcic horizons from Coimbatore, Tamil Nadu: Micromorphology and geochemical studies. Quat. Int. 2007, 175, 140-154. [CrossRef]

53. Sasso, G.D.; Zerboni, A.; Maritan, L.; Angelini, I.; Compostella, C.; Usai, D.; Artioli, G. Radiocarbon dating reveals the timing of formation and development of pedogenic calcium carbonate concretions in Central Sudan during the Holocene. Geochim. Cosmochim. Acta 2018, 238, 16-35. [CrossRef]

54. Magaldi, D. Calcareous crust (caliche) genesis in some Mollisols and Alfisols from southern Italy: A micromorphological approach. In Soil Micromorphology, 2nd ed.; Berkhamsted, Herts Academic: Hertfordshire, UK, 1983; pp. 623-636.

55. Carnicelli, S.; Ferrari, G.; Magaldi, D. Les accumulations carbonatées de type "calcrete" dans les sols et formations superficielles d'Italie méridionale. Méditerranée 1989, 68, 51-59. [CrossRef]

56. Magaldi, D.; Giammatteo, M. Microstrutture della crosta calcarea laminare (orizzonte petrocalcico) di due paleo suoli pleistocenici nell'agro di Cerignola (Foggia). II Quat. Ital. J. Quat. Sci. 2008, 21, 423-432.

57. Brewer, R. Fabric and Mineral Analysis of Soils. Soil Sci. 1965, 100, 73. [CrossRef]

58. Boschian, G. Soil Micromorphology of the Ripa Tetta Neolithic Village (Lucera, South Eastern Italy). In Proceedings of the UISPP Forlì, ABACO, Lucera, Italy, 8-14 September 1996; pp. 69-80.

59. Bertran, P.; Texier, J.-P. Facies and microfacies of slope deposits. Catena 1999, 35, 99-121. [CrossRef]

60. Leopold, M.; Völkel, J. Colluvium: Definition, differentiation, and possible suitability for reconstructing Holocene climate data. Quat. Int. 2007, 162, 133-140. [CrossRef]

61. Mücher, H.; Van Steijn, H.; Kwaad, F. Colluvial and Mass Wasting Deposits. In Interpretation of Micromorphological Features of Soils and Regoliths; Elsevier BV: Amsterdam, The Netherland, 2018; pp. 21-36. 
62. Cioni, R.; Levi, S.; Sulpizio, R. Apulian Bronze Age pottery as a long-distance indicator of the Avellino Pumice eruption (Vesuvius, Italy). Geol. Soc. London Spéc. Publ. 2000, 171, 159-177. [CrossRef]

63. Corrado, G.; Di Leo, P.; Giannandrea, P.; Schiattarella, M. Constraints on the dispersal of Mt. Vulture pyroclastic products: Implications to mid-Pleistocene climate conditions in the foredeep domain of southern Italy. Géomorphol. Relief Process. Environ. 2017, 23, 23. [CrossRef]

64. Paterne, M.; Guichard, F.; Labeyrie, J. Explosive activity of the South Italian volcanoes during the past 80,000 years as determined by marine tephrochronology. J. Volcanol. Geotherm. Res. 1988, 34, 153-172. [CrossRef]

65. Narcisi, B. Tephrochronology of a late quatternary lacustrine record from the monticchio maar (vulture volcano, southern Italy). Quat. Sci. Rev. 1996, 15, 155-165. [CrossRef]

66. Watts, W.; Allen, J.; Huntley, B.; Fritz, S. Vegetation history and climate of the last 15,000 years at Laghi Di Monticchio, southern Italy. Quat. Sci. Rev. 1996, 15, 113-132. [CrossRef]

67. Durand, N.; Monger, H.C.; Canti, M.G.; Verrecchia, E.P. Calcium Carbonate Features. In Interpretation of Micromorphological Features of Soils and Regoliths; Elsevier BV: Amsterdam, The Netherland, 2018; pp. 205-258.

68. Fedoroff, N.; Courty, M.-A.; Guo, Z. Palaeosoils and Relict Soils. In Interpretation of Micromorphological Features of Soils and Regoliths; Elsevier BV: Amsterdam, The Netherland, 2018; pp. 821-862.

69. Verrecchia, E.P. L'origine biologique et superficielle des croûtes zonaires. Bull. Soc. Géol. Fr. 1994, 165, 583-592.

70. Tandon, S.K.; Kumar, S. Semi-arid/arid zone calcretes: A review. In Palaeoenvironmental Reconstruction in Arid Lands; Singhvi, A.K., Derbyshire, E., Eds.; Oxford and IBH Publishing Co: New Delhi, India, 1999; pp. 109-152.

71. Cremaschi, M.; Nicosia, C. Corso di Porta Reno, Ferrara (Northern Italy): A study in the formation processes of Urban Deposits. II Quat. Ital. J. Quat. Sci. 2010, 23, 395-408.

72. Peña-Monné, J.; Rubio-Fernández, V.; González-Pérez, J.; Rodanés, J.; Picazo, J.; Médina, J.; Vazquez, M.; Sampietro-Vattuone, M.M.; Pérez-Lambán, F. Geoarchaeology of defensive moats: Its importance for site localization, evolution and formation process reconstruction of archaeological sites in NE Spain. J. Archaeol. Sci. 2014, 50, 383-393. [CrossRef]

73. Gebhardt, A. Impact of charcoal production activities on soil profiles: The micromorphological point of view. ArchéoSciences 2007, 127-136. [CrossRef]

74. Adderley, W.P.; Wilson, C.; Simpson, I.A.; Davidson, D.A. Anthropogenic Features. In Interpretation of Micromorphological Features of Soils and Regoliths; Elsevier BV: Amsterdam, The Netherland, 2018; pp. 753-777.

75. Kemp, R.A. Role of micromorphology in paleopedological research. Quat. Int. 1998, 51, 133-141. [CrossRef]

76. Compostella, C.; Mariani, G.S.; Trombino, L. Holocene environmental history at the treeline in the Northern Apennines, Italy: A micromorphological approach. Holocene 2014, 24, 393-404. [CrossRef]

77. Canti, M. Aspects of the chemical and microscopic characteristics of plant ashes found in archaeological soils. Catena 2003, 54, 339-361. [CrossRef]

78. Francis, G.; Cameron, K.C.; Kemp, R. A comparison of soil porosity and solute leaching after six years of direct drilling or conventional cultivation. Soil Res. 1988, 26, 637-649. [CrossRef]

79. Barker, P. Techniques of Archaeological Excavation; Routledge: London, UK, 2003.

80. Regattieri, E.; Isola, I.; Zanchetta, G.; Tognarelli, A.; Hellstrom, J.C.; Drysdale, R.N.; Boschi, C.; Milevski, I.; Temovski, M. Middle Holocene climate variability from a stalagmite from Alilica cave (southern Balkans). Alp. Mediterr. Quat. 2019, 32, 1-16.

81. Zanchetta, G.; Drysdale, R.N.; Hellstrom, J.; Fallick, A.E.; Isola, I.; Gagan, M.; Pareschi, M. Enhanced rainfall in the Western Mediterranean during deposition of sapropel S1: Stalagmite evidence from Corchia cave (Central Italy). Quat. Sci. Rev. 2007, 26, 279-286. [CrossRef]

82. Roberts, N.; Jones, M.D.; Benkaddour, A.; Eastwood, W.; Filippi, M.; Frogley, M.; Lamb, H.F.; Leng, M.J.; Reed, J.M.; Stein, M.; et al. Stable isotope records of Late Quaternary climate and hydrology from Mediterranean lakes: The ISOMED synthesis. Quat. Sci. Rev. 2008, 27, 2426-2441. [CrossRef]

83. Vannière, B.; Power, M.; Roberts, N.; Tinner, W.; Carrion, J.; Magny, M.; Bartlein, P.; Colombaroli, D.; Daniau, A.-L.; Finsinger, W.; et al. Circum-Mediterranean fire activity and climate changes during the mid-Holocene environmental transition (8500-2500 cal. BP). Holocene 2011, 21, 53-73. [CrossRef] 
84. Regattieri, E.; Zanchetta, G.; Isola, I.; Zanella, E.; Drysdale, R.N.; Hellstrom, J.C.; Zerboni, A.; Dallai, L.; Tema, E.; Lanci, L.; et al. Holocene Critical Zone dynamics in an Alpine catchment inferred from a speleothem multiproxy record: Disentangling climate and human influences. Sci. Rep. 2019, 9, 17829-17839. [CrossRef] [PubMed]

85. Marchegiano, M.; Francke, A.; Gliozzi, E.; Wagner, B.; Ariztegui, D. High-resolution palaeohydrological reconstruction of central Italy during the Holocene. Holocene 2018, 29, 481-492. [CrossRef]

86. Magny, M.; Vannière, B.; Zanchetta, G.; Fouache, E.; Touchais, G.; Petrika, L.; Coussot, C.; Walter-Simonnet, A.-V.; Arnaud, F.; Zanchetta, G. Possible complexity of the climatic event around 4300-3800 cal. BP in the central and western Mediterranean. Holocene 2009, 19, 823-833. [CrossRef]

87. Pelfini, M.; Leonelli, G.; Trombino, L.; Zerboni, A.; Bollati, I.M.; Merlini, A.; Smiraglia, C.; Diolaiuti, G.A. New data on glacier fluctuations during the climatic transition at $\sim 4,000$ cal. year BP from a buried log in the Forni Glacier forefield (Italian Alps). Rend. Lincei 2014, 25, 427-437. [CrossRef]

88. Sevink, J.; Bakels, C.C.; Attema, P.A.; A Di Vito, M.; Arienzo, I.; Di Vito, M. Holocene vegetation record of upland northern Calabria, Italy: Environmental change and human impact. Holocene 2019, 29, 633-647. [CrossRef]

89. Brooks, N. Cultural responses to aridity and increased social complexity in the Middle Holocene. Quat. Int. 2006, 151, 29-49. [CrossRef]

90. Nicoll, K. Geoarchaeological Perspectives on Holocene Climate Change as a Civilizing Factor In the Egyptian Sahara. In Biogeochemical Cycles; American Geophysical Union (AGU): Washington, DC, USA, 2013; pp. 157-162.

91. Zerboni, A.; Biagetti, S.; Lancelotti, C.; Madella, M. The end of the Holocene Humid Period in the central Sahara and Thar deserts: Societal collapses or new opportunities? Past Glob. Chang. Mag. 2016, 24, 60-61. [CrossRef]

92. Nicoll, K.; Zerboni, A. Is the past key to the present? Observations of cultural continuity and resilience reconstructed from geoarchaeological records. Quat. Int. 2019. [CrossRef]

93. Stephens, L.; Fuller, D.; Boivin, N.; Rick, T.; Gauthier, N.; Kay, A.; Marwick, B.; Armstrong, C.G.; Barton, C.M.; Denham, T.; et al. Archaeological assessment reveals Earth's early transformation through land use. Science 2019, 365, 897-902. [CrossRef] [PubMed]

94. Boles, O.; Shoemaker, A.; Mustaphi, C.J.C.; Petek, N.; Ekblom, A.; Lane, P.J. Historical Ecologies of Pastoralist Overgrazing in Kenya: Long-Term Perspectives on Cause and Effect. Hum. Ecol. 2019, 47, 419-434. [CrossRef]

95. Evans, R. The erosional impacts of grazing animals. Prog. Phys. Geogr. Earth Environ. 1998, 22, $251-268$. [CrossRef]

96. Henry, D.O.; E Cordova, C.; Portillo, M.; Albert, R.M.; DeWitt, R.; Emery-Barbier, A. Blame it on the goats? Desertification in the Near East during the Holocene. Holocene 2016, 27, 625-637. [CrossRef]

97. Zerboni, A.; Mariani, G.S.; Castelletti, L.; Ferrari, E.S.; Tremari, M.; Livio, F.; Amit, R. Was the Little Ice Age the coolest Holocene climatic period in the Italian central Alps? Prog. Phys. Geogr. Earth Environ. 2019, 0309133319881105. [CrossRef]

98. Zerboni, A.; Perego, A.; Mariani, G.S.; Brandolini, F.; Al Kindi, M.; Regattieri, E.; Zanchetta, G.; Borgi, F.; Charpentier, V.; Cremaschi, M. Geomorphology of the Jebel Qara and coastal plain of Salalah (Dhofar, southern Sultanate of Oman). J. Maps 2020, 16, 187-198. [CrossRef]

99. Wright, D.K. Humans as Agents in the Termination of the African Humid Period. Front. Earth Sci. 2017, 5, 4. [CrossRef]

100. Zerboni, A.; Nicoll, K. Enhanced zoogeomorphological processes in North Africa in the human-impacted landscapes of the Anthropocene. Geomorphology 2019, 331, 22-35. [CrossRef]

101. Liritzis, I.; Laskaris, N.; Vafiadou, A.; Karapanagiotis, I.; Volonakis, P.; Papageorgopoulou, C.; Bratitsi, M. Archaeometry: An Overview. Sci. Cult. 2020, 6, 49-98. [CrossRef]

(C) 2020 by the authors. Licensee MDPI, Basel, Switzerland. This article is an open access article distributed under the terms and conditions of the Creative Commons Attribution (CC BY) license (http://creativecommons.org/licenses/by/4.0/). 